Final Technical Report 1987

\section{United States \\ Department of \\ Agriculture}

Forest Service

Uars

Southeastern Forest

Experiment Station
Use of Municipal Sewage Sludge for Improvement of Forest Sites in the Southeast

Charles R. Berry

Research Paper 


\title{
Use of Municipal Sewage Sludge for Improvement of Forest Sites in the Southeast
}

\author{
Charles R. Berry, Plant Pathologist \\ Institute for Mycorrhizal Research and Development \\ Athens, Georgia
}

\begin{abstract}
In eight field experiments dried municipal sewage sludye was applied to forest sites before planting of seedlings. In all cases, tree growth was faster on sludge-amended plots than on plots that received fertilizer and lime or no amendment.

In all studies, concentrations of total nitrogen in the soil were higher on sludge plots than on control or fertilizer plots, even on good forest sites. In seven of the eight studies, concentrations of phosphorus also were higher on sludge plots than on control or fertilizer plots. Nitrogen and phosphorus tended to be higher in foliage from trees growing on sludge plots.

Deep subsoiling was beneficlal regardless of soil amendment. Where weeds were plentiful at the outset, they became serious competitors on plots receiving sludge.
\end{abstract}

Keywords: Reclamation, borrow pit, tree growth, Pinus taeda, Liquidambar styraciflua, soil nutrients, subsoiling.

\section{Introduction}

Municipal sewage sludge contains abundant plant nutrients and is an effective long-lasting amendment for improving normal forest sites and for reclamation of disturbed sites in the Southeast. That conclusion is demonstrated by eight studies of the effects of dried sewage sludye on soils, tree growth, and element concentrations in tree foliage in the Southeastern United States. Of these studies, four were on borrow pits, one on a kaolin spoil, and one in the Tennessee Copper Basin. Two studies were on routine reforestation sites in South Carolina. Although in some cases early results were published previously, this paper contains updated information and draws certain conclusions not possible in the earlier reports.
The use and effects of sewage sludges and effluents for reclamation of surface coal mines and other disturbed sites, as well as effects of sludge disposal on land, have been studied extensively (Bledsoe 1981; Cole and others 1986; National ASU\&LGC 1973; Page and others 1983; Sopper and Kardos 1973; Sopper and Kerr 1979; Sopper and others 1982).

The effects of sewage sludge and other organic wastes on soils are discussed by Elliott and Stevenson (1977), and many aspects of reclamation including the use of sewage sludge are discussed by Schaller and Sutton (1978). Two recent guides that deal specifically with revegetation of coal mine spoils are by Vogel (1981) and Sopper and Seaker (1983). Possible health risks associated with sewage sludge have also been reviewed (Bitton and others 1980).

Effects of sewage sludge on tree growth on normal forest sites in the Southeast were reported by Wells and others (1985) and Mckee and others (1986). Hinkle (1982) used sludge to reclaim abandoned pyrite mines, and sludge has been used on other disturbed sites (Berry 1977, 1979b, 1982, 1985b; Berry and Marx 1977, 1980; Kormanik and Schultz 1985; and Ruehle 1980). Spot application of sludge, a technique of potential value in rough terrain, has been found to aid initial growth of both loblolly pine (Pinus taeda L.) and hardwoods (Berry 1979a, 1983).

\section{A Hord About Sewage Sludge}

Sewage sludge is obtained from the processing of domestic or industrial wastewater. The initial or primary 
treatment of wastewater is usually designed to remove settleable solids by some form of physical separation (screening or gravity settling). Next, the wastewater is subjected to chemical or biological processes designed to remove dissolved and colloidal material. Thereafter, wastewater (or effluent) may receive various combinations of physical and chemical treatments. The solids removed during these processes are usually high in organic matter, are biologically unstable, and are characterized by offensive odors. These materials may be stabilized by aerobic or anaerobic digestion. When sludge is removed from digesters, it is in liquid form (containing 3 to 6 percent solids) and can be transported in pipelines, tank cars, or tank trucks. With proper equipment, it can be directly applied to land if State and Federal EPA regulations are met. Usually, however, some form of dewatering process such as sandbed drying, vacuum filtering, or centrifugation is employed before disposal to produce a dry or semidry, semisolid material that can be transported in open trucks and applied to land with standard agricultural equipment. If the dewatering is carried out by vacuum filtration or centrifugation, a chemical flocculant is employed to improve separation of liquid from solid material. The flocculant gives the sludge a semiliquid, gellike character that makes application to land difficult. McCalla and others (1977) discuss the physical, chemical, and biological properties of sludges in detail.

The method of handling sewage sludge depends on solids content. Sludge containing up to 10 percent total solids can be pumped with special equipment. Slurries with up to 5 or 6 percent total solids may be applied with field sprinklers. The sludge must contain at least 25 to 30 percent solids before it can be handled with a shovel or pitchfork.

All sludges used in the experiments reported in this paper were anaerobically digested and sandbed dried and contained at least 35 percent solids. They were also characterized by low heavy metal concentrations; for example, less than
$10 \mathrm{p} / \mathrm{m} \mathrm{Cd}$ and $250 \mathrm{p} / \mathrm{m} \mathrm{Zn}$. An analysis of the sewage sludges used in most of the experiments reported here is shown in table 1.

\section{Characteristics of Sites and Studies}

All experimental sites were prepared by mechanically removing all woody vegetation present, then by grading, if necessary, to eliminate gullies. Amendments were thoroughly incorporated into surface soil to a depth of 15 to $20 \mathrm{~cm}$ by disking. Control plots (no amendment) were similarly disked. In addition, all sites were subsoiled to a depth of from 61 to $92 \mathrm{~cm}$ after disking except in Study 3 where a variety of physical soil treatments were tested and in Study 7 where disking was compared with a single subsoiling treatment. Spacing between subsoiled furrows and the pattern of furrows (parallel lines or perpendicular lines) varied with the experiment. In recent experiments, subsoiling was done in early fall to allow furrows to settle before planting. Seedlings were planted the following spring in the closed furrows. Treatment plots containing 16 to 36 trees were replicated three to six times. A randomized complete-block design was used in all except Study 6, in which treatments were completely randomized. Data were subjected to analysis of variance, and means were separated by Duncan's multiple range test.

Soil samples for chemical analysis were collected from the plots in all studies in August 1985. Nine subsamples, taken from the top $15 \mathrm{~cm}$ of mineral soil, were composited for each replicate. The samples were air-dried in the laboratory and screened to a particle size of no - more than $2 \mathrm{~mm}$. All chemical analyses were done by A\&L Laboratories, Inc., 411 N. Third Street, Memphis, TN.

In the fall of 1985, the heights and root-collar diameters (D) of all trees in all studies were measured. Values for $D^{2} H$ were then computed for each tree and summarized. $\mathrm{D}^{2} \mathrm{H}$ has been shown to be a reliable surrogate measure for aboveground biomass of loblolly pine, and it also appears to be a good 
indicator of stem weight and stem volume (Hatchell and others 1985).

Physical and chemical properties of the upper $16 \mathrm{~cm}$ of the soil at the eight study locations are presented in table 2. Additional information on the sites and a description of each study are provided in the next section.

\section{Individual Studies}

Study 1

This study was installed on a borrow pit $(B P-1 a)$ on the Savannah River Forest Station, at the Savannah River Plant, Aiken, SC, in 1976. The pit originally overlain with Fuqua and Wagram soils, was created in 1950-1952. Soil and substratum to a depth up to $6 \mathrm{~m}$ had been removed, leaving a severely compacted ground surface. This borrow pit, like most others at the Savannah River Forest Station had been planted with loblolly pine seedlings in the early 1950's, but little or no fertilizer was used and no subsoiling was done. In 1976 many trees were still surviving, but few were taller than $3 \mathrm{~m}$. The area was prepared for the study by removing all vegetation and subsoiling to a depth of $0.9 \mathrm{~m}$ with perpendicular furrows spaced $1.2 \mathrm{~m}$ apart in both directions. Loblolly pine seedlings with ectomycorrhizae formed by Pisolithus tinctorius (Pers.) Coker \& Couch or naturally occurring Thelephora terrestris (Ehrh.) ex Fr. were planted $6726 / \mathrm{ha}(1.2 \mathrm{~m} \times 1.2 \mathrm{~m})$ in plots amended as follows:

No fertilizer (control)
Fertilizerl \& lime ${ }^{2}$
Fertilizer \& lime + tree bark 3
Fertilizer \& lime + ash
Fertilizer \& lime + bark + ash
Sewage sludge
Sewage sludge + bark
Sewage sludge + ash
Sewage sludge + bark + ash

${ }^{1} 560 \mathrm{~kg} / \mathrm{ha}$ of commercial 10-10-10 fertilizer.

$22240 \mathrm{~kg} / \mathrm{ha}$ of dolamitic 1 imestone.

${ }^{3}$ Milled pine bark, bottom furnace ash, and sewage sludge were applied at rate of $125 \mathrm{~m}^{3} / \mathrm{ha}$, or approximately $1.3 \mathrm{~cm}$ deep. With sewage sludge, this rate was equivalent to a dry weight of $34000 \mathrm{~kg} / \mathrm{ha}$.
The area was thoroughly disked to incorporate amendments, then sown with ky 31 fescue seed before planting pine seedlings. At age 5, all plots were thinned to 2,691 trees per hectare. Naturally occurring Pisolithus tinctorius formed abundant ectomycorrhizae on all seedlings during the first year in the field, precluding any mycorrhizal comparisons.

Sewage sludge alone or with bark and/or ash dramatically improved early seedling yrowth (fig. 1) and production of grass biomass, compared with other soil treatments (Berry and Marx 1980). After 3 years, grass biomass was five times greater on sludge than on other plots. There was no significant weed growth in this study.

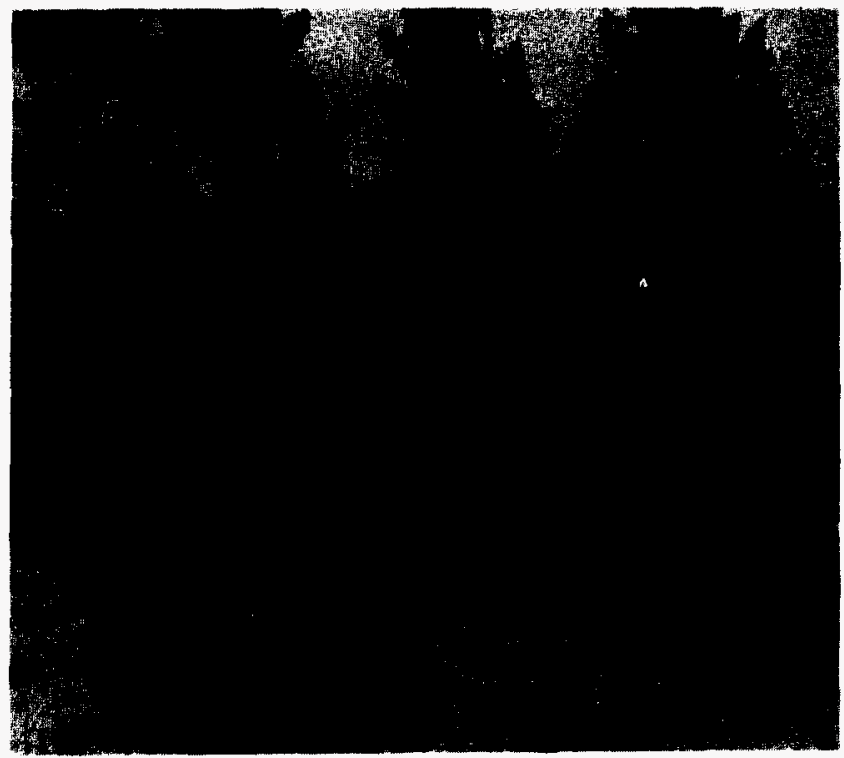

Figure 1.--Three-year-old loblolly pines grawing on borrow pit plots. Plot in foreground anended with 560 $\mathrm{kg} / \mathrm{ha}$ of $10-10-10$ fertilizer plus $2240 \mathrm{~kg} / \mathrm{ha}$ of $11 \mathrm{me}$. Plots in background anended with $34 \mathrm{mg} / \mathrm{ha}$ of sludge. The approximately $7-m-h i g h$ wall indicates anount of material removed in creation of borrow pit.

At age 10 , plots receiving sludge had more than 2 times as much nitrogen and more than 25 times as much phosphorus as control and fertilized plots. Organic matter content and cation exchange capacity were also considerably higher on sludge plots (table 3 ). By age 10 , crowns had closed on the plots receiving sludge, and $D^{2} H$ was many times higher on these plots than on fertilized or control plots (table 4). 
Study 2

This study was installed on a borrow pit (BP-1b) adjacent to Study 1. Site history and site preparation were the same as for Study 1 and preparation was carried out at the same time. Treatments consisted of $0,17,34$, or $68 \mathrm{Mg} / \mathrm{ha}$ of sewage sludge $(2 \% \mathrm{~N}, 1 \% \mathrm{P}$, and $0.5 \% \mathrm{~K})$. Plots were planted with sweetgum (Liquidambar styraciflua L.) from two different half-sib families.

After 5 years, there was no difference in growth between the two sweetgum families but the influence of sludge amendment was dramatic. Although competition by fescue, planted as a groundcover, may have retarded early tree growth to some extent, competition from weeds was not significant. Fifth-year growth on unamended plots was poor; tree height averaged less than $1 \mathrm{~m}$. On plots amended with $17 \mathrm{Mg} / \mathrm{ha}$ of sludge, mean height was $2.75 \mathrm{~m}$. On plots amended with 34 or $68 \mathrm{Mg} / \mathrm{ha}$, mean height was over $3.6 \mathrm{~m}$ (Kormanik and Schuitz 1985).

At age 10, the improvements in soil properties associated with $34 \mathrm{Mg} / \mathrm{ha}$ of sludge were similar to those observed in Study 1 (table 5). The sweetgum growth response was best after 34 and $68 \mathrm{Mg} / \mathrm{ha}$ applications, but did not differ significantly between these two treatments (table 6).

Study 3

This study was installed on a borrow pit (BP-2) originally overlain with Gunter sand. Creation of this borrow pit exposed a substratum on which trees and other vegetation grew poorly.

Eighteen treatments ( 2 amendments $x$ 9 mechanical site preparation treatments) were installed. Anaerobically digested sewage sludge was obtained from Macon, GA. Sludge was applied to half of the study plots at a rate of $17 \mathrm{Mg} / \mathrm{ha}$, and fertilizer (10-10-10) and pulverized dolomitic limestone were applied at a rate of $1121 \mathrm{~kg} / \mathrm{ha}$ and $2242 \mathrm{~kg} / \mathrm{ha}$, respectively, to the remaining plots. Amendments were appl ied in September 1978 and incorporated by double-disking to a depth of $15 \mathrm{~cm}$.
Nine mechanical site preparation treatments varied subsoiling depth and spacing of furrows running in either one or two directions. These treatments were applied to both fertilized plots and plots amended with sewage sludye. During the autumn of 1978 , the study site was seeded with Ky 31 fescue (Festuca arundinacea Schreb.) at $34 \mathrm{~kg} / \mathrm{ha}$.

Loblolly pine seedlings (Livingston Parish source) that had been inoculated and heavily colonized by the ectomycorrhizal fungus $P$ isolithus tinctorius (Pt index 88) were planted in March 1979. Seedlings were planted at a density of 1,914 trees per hectare and always in a subsoiled furrow except on disked-only plots. No weed control was necessary.

The effect of sewage sludge on growth after 4 years was striking (Berry 1985b). Trees on these plots grew an average of 37 percent more in height and 76 percent more in d.b.h. than trees grown on fertilizer plots. Four-year survival was not influenced by treatment.

Subsoiling interacted with amendments in its influence on tree growth (Berry 1985b). After 4 years on fertilized plots, trees grew 9 percent more in height and 17 percent more in diameter on plots subsoiled $46 \mathrm{~cm}$ deep than on plots subsoiled $92 \mathrm{~cm}$ deep. When sewage sludge was used, however, there was significantly more growth $(4.5 \%$ more height and $7.4 \%$ more d.b.h.) when plots were subsoiled to a depth of $92 \mathrm{~cm}$ rather than $46 \mathrm{~cm}$. After 4 years, no growth differences due to spacing of furrows or whether furrows were parallel or perpendicular were detected.

Seven years after treatment, plots receiving sludge had more than 2 times as much nitrogen, 10 times as much phosphorus, and 2 times as much organic matter as plots that were fertilized (table 7). $\mathrm{D}^{2} \mathrm{H}$ values for trees on plots receiving sludge were about four times those on fertilized plots. Subsoiling was beneficial, but growth through age 7 did not differ significantly between the $46-$ and the $92-\mathrm{cm}$ treatment depths (table 8 ). 
Study 4

This study, also installed on a borrow pit (BP-3), was designed to determine whether several hardwoods besides sweetgum could grow well on substratum material amended with sludge and subsoiled. A split-plot experiment tested $68 \mathrm{Mg} / \mathrm{ha}$ of fresh sludge from Athens, GA, or fertilizer $(1120 \mathrm{~kg} / \mathrm{ha}$ of $10-10-10+2240 \mathrm{~kg} / \mathrm{ha}$ of dolomitic lime) or nothing in major plots and compared the relative adaptability of six species to a sludge-reclaimed borrow pit. Species compared in this experiment were sycamore (Platanus occidental is $L_{\text {. }}$ ), green ash Traxinus pennsylvanica Marsh.), sawtooth oak (Quercus acut issima Carruthers), and yellow-poplar (Liriodendron tulipifera L.) as well as loblolly pine and sweetgum. Twenty-five trees were planted at a density of 1,682 trees per hectare in each treatment plot. All species were planted in sludge and fertilizer plots, while only sweetgum, green ash, and loblolly pine were planted in the control (no amendment) plots.

On loblolly pine, sweetgum, and green ash, mycorrhizal inoculation treatments were applied, but in all cases the noninoculated seedlings became contaminated soon after planting in the field, precluding any information on mycorrhizal effect.

A highly significant species $x$ fertility interaction affecting $\mathrm{D}^{2} \mathrm{H}$ was observed after the second growing season. Growth of several, if not all, species in this experiment was retarded by weed competition, which has been exceptionally heavy in sludge plots.

By age 4, nitrogen, phosphorus, and organic matter contents were no longer significantly higher on fertilized than on control plots. Sludge plots had more of these elements than the control plots (table 9). In general, trees performed better on sludge plots than on those receiving fertilizer, but the advantage varied considerably by species (table 10). For the three main species in the study, the percentage of improvement in $\mathrm{D}^{2} \mathrm{H}$ attributable to sludge was greatest in green ash, next greatest in sweetgum, and least in loblolly pine. Even so, $\mathrm{D}^{2 \mathrm{H}}$ in loblolly pine was almost five times as high on sludge as on control plots (table 11).

Study 5

This study was installed on a kaolin spoil to determine the feasibility of reclaiming this type of spoil with sludge. About 8498 ha in Georgia had been surface-mined for kaol in clay by 1973, and it was estimated that up to an additional 120000 ha $(297,000$ acres) of land will eventually be mined (May 1977). Berry and Marx (1977) found that loblolly pine seedlings grew well in kaolin spoil in microplots when amended with either fertilizer or sewage sludge.

Sweetyum seedlings were planted in plots amended with $34 \mathrm{Mg} / \mathrm{ha}$ of old sewage sludge from Athens, GA, $1120 \mathrm{~kg} / \mathrm{ha}$ of 10-10-10 fertilizer, or nothing. Twenty-five trees at a density of 1,682 trees per hectare were planted in each treatment plot.

Four years after treatment, sludge plots had about 10 times as much nitrogen, 7 times as much phosphorus, and 5 times as much organic matter as fertilized plots (table 12). As a result, $\mathrm{D}^{2} \mathrm{H}$ on sludge plots was almost four times as large as on fertilized plots and more than four times as large as on control plots (table 13).

\section{Study 6}

This study was installed on a severely eroded and devastated site in the Tennessee Copper Basin originally overlain with Hayesville sandy loam.

The Tennessee Copper Basin is unique in the Eastern United States in that all natural vegetation on 7,000 acres was killed, and the surrounding 17,000 acres were reduced to grassland in the middle to late 1800 's by air pollution resulting from primitive processing of copper ore. The subsequent severe erosion of topsoil left deeply gullied subsoil exposed over thousands of acres. As late as the early 1970 's, chronic air pollution continued to retard growth and reduce survival 
of trees in the area. Recent technological innovations, however, have greatly reduced sulfur dioxide emissions.

Several other obstacles to reforestation of the area are lack of soil nutrients and organic matter, insufficient moisture during dry periods, and desiccation of trees by wind.

In a completely randomized design of four treatments, noninoculation or inoculation with Pisolithus tinctorius treatments were combined factorially with 34 $\mathrm{Mg} / \mathrm{ha}$ of fresh sludge from Athens, GA, or fertilizer (896 kg/ha of 10-10-10 with $1417 \mathrm{~kg} / \mathrm{ha}$ of $\mathrm{CaO}$ ). Trees were planted at 11 960/ha and thinned after 5 years to $3322 / \mathrm{ha}$.

After 4 years, all three species had grown significantly better on plots amended with sludge than on those with fertilizer. Shortleaf pine grew more in height on sludge plots, but not in rootcollar diameter or D2H. Loblolly and Viryinia pines grew more in height, root-collar diameter, and $D^{2 H}$ on siudgeamended plots than on fertilizer-amended plots. Pt ectomycorrhizae produced no significant increase in growth. Loblolly and Virginia pines, which grew at approximately equal rates, were significantly larger than shortleaf (Berry 1982).

As in the studies on borrow pits, the nitrogen, phosphorus, and organic matter contents of the soil 10 years after treatment were considerably higher on sludge plots than on fertilized plots (table 14). At age 10, loblolly pines were tallest, Virginia pines (Pinus virginiana Mill.) next, and shortleaf pines (P. echinata Mi11.) markedly shorter. All three species grew best on sludge plots (table 15).

Study 7

This study was installed on a good forest site with Urangeburg soil at the Savannah River Forest Station. A splitsplit-plot design was replicated in four blocks to test three fertility treatments ( $34 \mathrm{Mg} / \mathrm{ha}$ of old sludge from Athens, $280 \mathrm{~kg} / \mathrm{ha}$ diammonium phosphate and control) and two mechanical site preparation treatments (subsoiling and disking). Sweetgum seedlings with two mycorrhizal treatments, inoculation with Glomus spp. and no inoculation, were planted the following spring at a density of 1076/ha. In an effort to control weeds, $23 \mathrm{~kg} / \mathrm{ha}$ of simazine

(Princep F-G) were applied in early 1982 and later in the season a 1-percent solution of Round-up was applied at a rate of $3.7 \mathrm{~L} / \mathrm{ha}$. Chemical control of weeds was not adequate, however, and additional weed control by disking has been necessary. In July 1983, sludge was applied to one-third of the plots at a rate of $34 \mathrm{Mg} / \mathrm{ha}$. After sludge application, all plots were double-disked and in September one-half of each block was subsoiled to a depth of $76 \mathrm{~cm}$ with parallel furrows spaced at $122 \mathrm{~cm}$.

Examinations of root systems revealed that seedlings initially nonmycorrhizal became colonized with resident mycorrhi$z a l$ fungi within the first months in the field. It therefore was not possible to measure the possible influence of mycorrhizal treatment on growth.

Two years after treatment, soil nutrient levels were significantly higher on sludge plots than on fertilized or control plots (table 16). Subsoiling improved survival and growth. Both sludge and fertilizer application improved growth, and differences between the two treatments were not statistically significant (table 17).

\section{Study 8}

This study was installed on a good forest site with Dothan and Norfolk soil at the Savannah River Forest Station. Sweetgum seedlings were planted at a density of 1,682 trees per hectare in plots amended with fresh Athens slidge at $34 \mathrm{Mg} / \mathrm{ha}$, fertilizer $(1480 \mathrm{~kg} / \mathrm{ha}$ diammonium phosphate and $1100 \mathrm{~kg} / \mathrm{ha}$ ammonium nitrate), or nothing. Early results from this study were interesting in that trees on control plots grew better than trees on plots amended with sludge or fertilizer. Data presented here indicate, however, that after the 4 th year, insufficient nutrients were limiting growth on fertilizer and control plots. 
At age 7, differences in nitrogen, phosphorus, and organic matter contents among sludge, fertilizer, and control plots are still apparent. The phosphorus level is much lower on control than on fertilizer or sludge plots (table 18). In terms of $D^{2} H$, tree growth has been about twice as fast on sludge plots as on fertilized or control plots (table 19).

\section{Combined Results}

\section{Effects on Soil Properties}

The sites for Studies 1 through 6 were low in nitrogen $(<175 \mathrm{p} / \mathrm{m}$ ), phosphorus $(<4 \mathrm{p} / \mathrm{m})$, and organic matter $(<$ $0.4 \%$ ) and were regarded as reclamation areas. The two "good" forest sites had considerably higher concentrations of nitrogen $(>238 \mathrm{p} / \mathrm{m})$ and organic matter (>1.6\%) but only one of the two (Study $8 T$ had abundant $P(31 \mathrm{p} / \mathrm{m})$. Nevertheless, growth of trees on unamended control plots was excellent on both sites 7 and 8 .

In all studies, the concentrations of total nitrogen were higher on sludye plots than on control or fertilizer plots, even on the two good forest sites. In all studies but one (Study 7), phosphorus was higher on sludge plots than on fertilizer plats. In Study 8 , diammonium phosphate $(1480 \mathrm{~kg} / \mathrm{ha})$ and ammonium nitrate $(1100 \mathrm{~kg} / \mathrm{ha})$ were applied to fertilizer plots so that, initially, $N, P$, and $K$ would be comparable with sludge plots. Organic matter and cation exchange capacity also were usually higher on sludge plots than on fertilizer plots. Potassium levels were usually about equal on sludge and fertilizer plots. Levels of $\mathrm{Ca}$ and $\mathrm{Mg}$ and $\mathrm{pH}$ were always higher on fertilizer plots.

Three studies involving three pine and one hardwood species were 10 years old when data were last taken. The relative nutrient status of sludge, fertilizer, and control treatments that existed in the soil when the studies were installed appears to be just as strong today.

\section{Effects on Tree Growth}

In all cases, sewage sludge produced faster growth than fertilizer over the 2to 10-year period covered by the reported studies. In most studies where a "no treatment" control was installed in addition to a fertilizer treatment, an application of 560 to $1120 \mathrm{~kg} / \mathrm{ha}$ of 10-10-10 plus $2240 \mathrm{~kg} / \mathrm{ha}$ of dolomitic lime produced little increase in growth over the "no treatment" control, if any.

In studies where more than one species was examined, there appeared to be a strong interaction between species and type of fertility added. For example, in the Copper Basin study, D ${ }^{2} H$ of shortleaf pine trees on sludge plots was 164 percent better than on fertilizer plots, while U H of Virginia pine was 296 percent more on sludye than on fertilizer plots. Similarly, in the borrow pit study where yrowth of several hardwood species was compared, diameters of none of the hardwood species differed significantly on sludge plots, while there was considerable difference on fertilizer plots, on which sycamore and sawtooth oak grew faster than green ash which in turn yrew faster than yellow-poplar.

The quantity of sludge required to produce the most rapid growth of sweetgum was determined on a borrow pit (Study 2). The opt imum growth occurred with $34 \mathrm{Mg} / \mathrm{ha}$ of sludge, and there was no increase in growth when the level of sludge was increased to $68 \mathrm{Mg} / \mathrm{ha}$. These data (table 20) agree with results reported previously (Berry 1977) for an eroded forest site (Madison soil series) for loblolly and shortleaf pines.

\section{Duration of Benefits}

The long-lasting benefits from sludge application are illustrated by growth of three pine species, 10 years old, in the Copper Basin (figs. 2,3 , and 4 ), by 10 -year-old loblolily pine growing on a borrow pit (fig. 5) and by 7-year-old sweetgum yrowing on a good forest site (fig. 6). All these examples show rapidly accelerating growth of trees on sludge plots. In none of these 
cases is there an indication of a slowdown in growth on sludge plots. Growth on the fertilizer and control plots, however, varies with the site and the type and frequency of fertilizer application. of particular interest is response of sweetgum on Dothan and Norfolk soils, where growth on the sludge plots was no better than on control plots for the first 4 years. Measurements taken after the 5 th and 7 th years, however, indicate an acceleration of growth of trees on sludge plots, while growth rates on control and fertilizer plots remain about equal and much slower than on sludge plots.

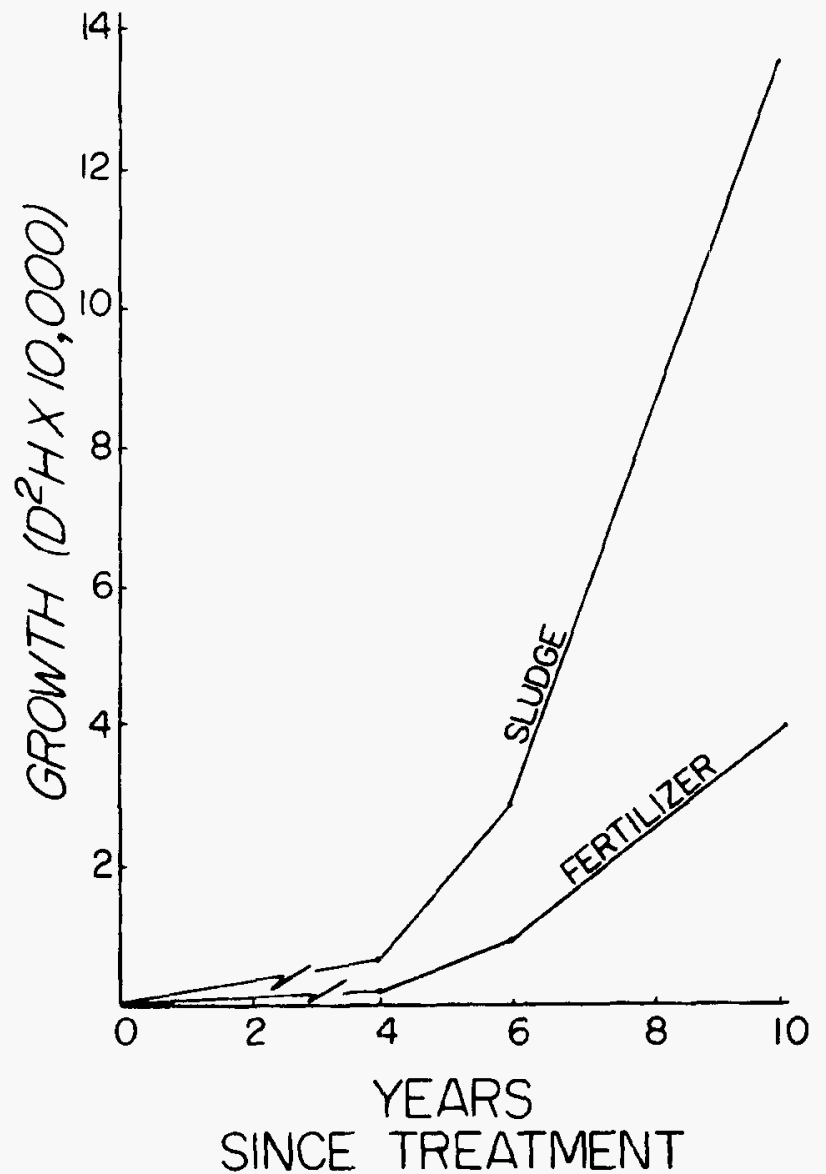

Figure 2.--Growth of loblolly pine on amended plots in the Copper Basin as influenced by sludge $(34 \mathrm{mg} / \mathrm{ha}$ ) and fertilizer (896 kg/ha of 10-10-10 fertilizer plus $1417 \mathrm{~kg} / \mathrm{ha} \mathrm{CaO}$ ).

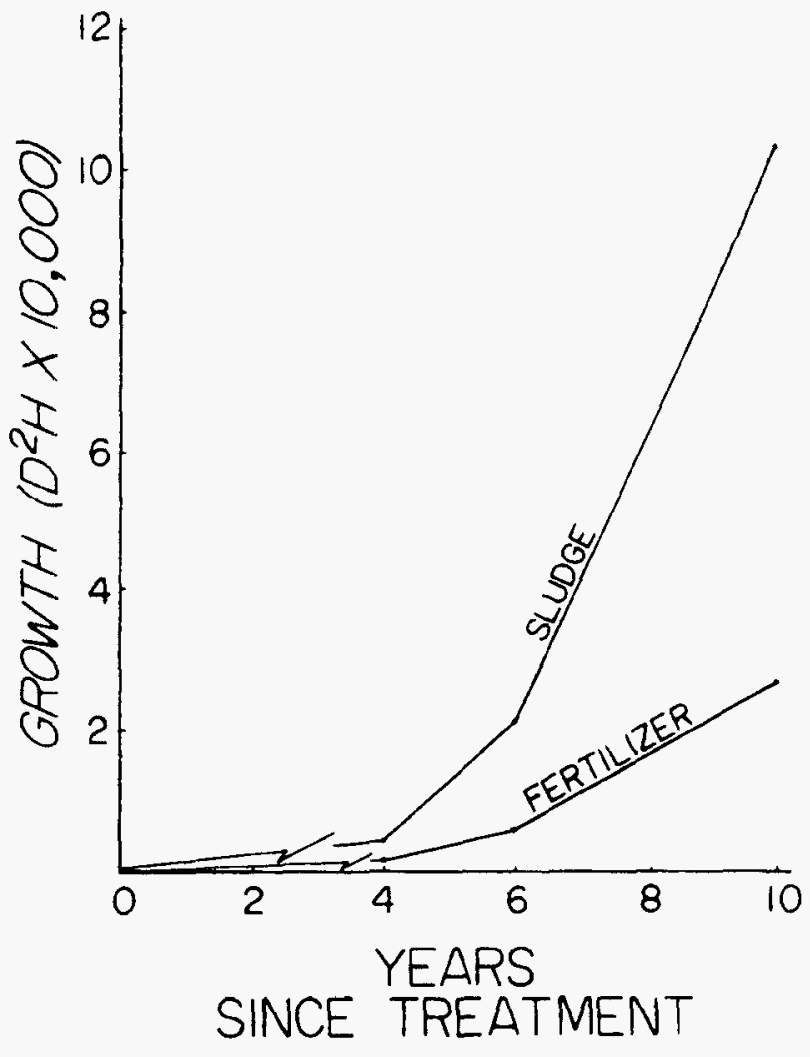

Figure 3.--6rowth of Virginia pine on mended plots in the Copper Basin as influenced by sludge (34 Mg/ha) and fertilizer $(896 \mathrm{~kg} / \mathrm{ha}$ of $10-10-10$ fertilizer plus $1417 \mathrm{~kg} / \mathrm{ha} \mathrm{CaO}$ ).

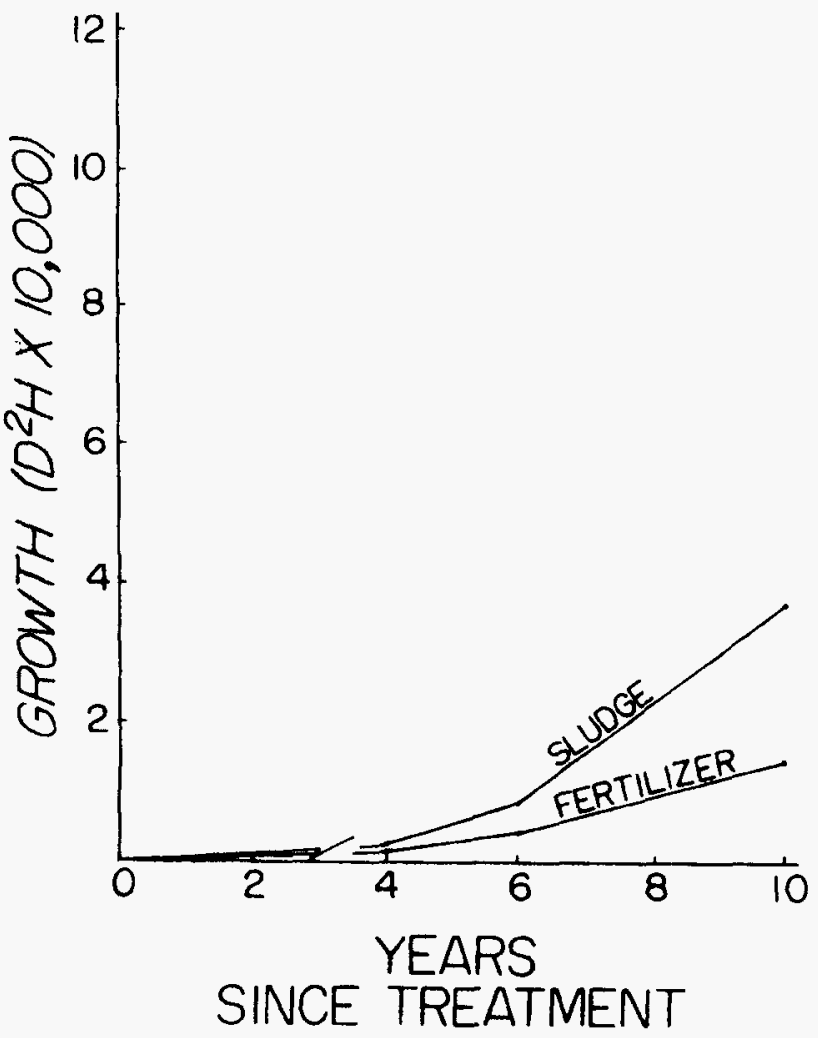

Figure 4.--Growth of shortleaf pine on amended plots in the Copper Basin as influenced by sludge ( $34 \mathrm{Mg} / \mathrm{ha})$ and fertillzer $896 \mathrm{~kg} / \mathrm{ha}$ of 10-10-10 fertilizer plus $1417 \mathrm{~kg} / \mathrm{ha}$ of $\mathrm{CaO}$ ). 


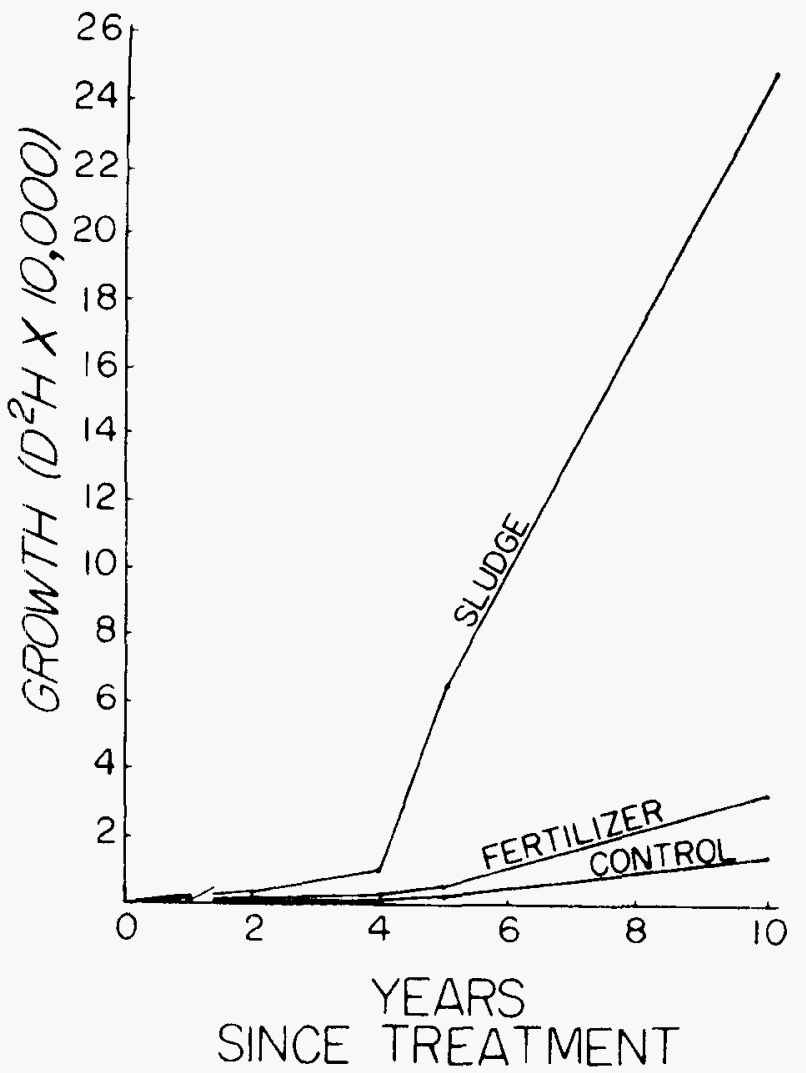

Figure 5.--growth of loblolly pine on a borrow pit as influenced by sludge $(34 \mathrm{Mg} / \mathrm{ha})$ and fertilizer ( 560 $\mathrm{kg} / \mathrm{ha}$ of 10-10-10 fertilizer plus $2240 \mathrm{~kg} / \mathrm{ha}$ of dolomitic l/me).

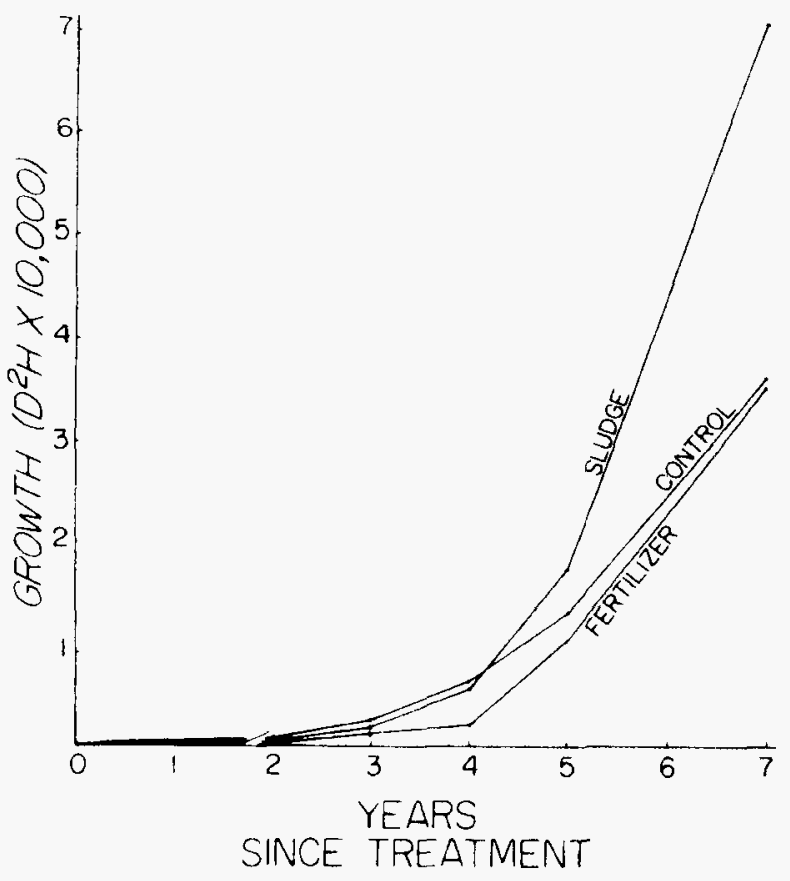

Figure 6.--Growth of sweetgum on a good forest site with Dothan and Morfolk solls as influenced by sludge (34 Mg/ha) and fertilizer (1480 kg/ha of diammonium phosphate plus $1100 \mathrm{~kg} / \mathrm{ha}$ ammonium nitrate).
Subsoiling

Deep subsoiling--ripping of soil up to $y 1 \mathrm{~cm}$ deep--was used in most studies, and studied as a treatment variable on three sites. In an early study, subsoiling with parallel furrows spaced 80 $\mathrm{cm}$ apart and $60 \mathrm{~cm}$ deep was compared with disking $15 \mathrm{~cm}$ deep (Berry 1979b). Both loblolly and shortleaf pines produced significantly higher $\mathrm{U}^{2} \mathrm{H}$ values (19\% higher for loblolly and 38\% higher for shortleaf) on subsoiled plots than on plots that were disked only. In a study on Orangebury soil (Study 7), growth of sweetgum after 2 years on disked plots was compared with growth on subsoiled plots (parallel furrows spaced $122 \mathrm{~cm}$ apart and $60 \mathrm{~cm}$ deep). There were significant increases in height, diameter, and $D^{2} H$ in trees on subsoiled plots compared with trees on disked plots. There was a 47-percent increase in $\mathrm{D}^{2} \mathrm{H}$ on subsoiled plots compared with that on plots that had been disked only. In Study 3, eight intensities of subsoiling plus disking were compared on fertilizer and sludge plots on a borrow pit planted with loblolly pine. When sewage sludge was applied, any degree of subsoiling was significantly better than disking. When fertilizer was used as an amendment, any degree of subsoiling was better than disking for height, but not diameter yrowth. For $\mathrm{B}^{2} \mathrm{H}$ on fertilized plots, subsoiling to $46 \mathrm{~cm}$ was significantly better than disking. Neither subsoiling in two directions (perpendicular pattern) rather than one nor spacing furrows at $122 \mathrm{~cm}$ instead of 244 $\mathrm{cm}$ offered any improvement in growth.

\section{Herbaceous Groundcover}

In several studies the sites were seeded to $\mathrm{Ky} 31$ fescue, and in one study grass biomass production was measured. Lush stands of herbaceous material were sometimes produced when sewaye sludge was applied. In no case did noxious weeds appear to be introduced by sludge application, but in Study 4 sludge application stimulated weeds al ready on the site sufficiently to cause severe competition to the planted trees. In a block where weeds were sparse, tree 
growth was excellent. In other blocks where weed growth was luxuriant, tree growth was moderate. The detrimental effects of weed competition were also illustrated in an early sludge study (Berry 1977) not included in the present paper. The stimulation of ragweed and crabyrass in that study was so great that shortleaf pine did not survive on plots amended with $68 \mathrm{Mg} / \mathrm{ha}$ of sludge (table 20). In addition, both survival and yrowth of shortleaf were less on plots amended with $34 \mathrm{Mg} / \mathrm{ha}$ than on plots amended with $17 \mathrm{Mg} / \mathrm{ha}$. Loblolly pine tolerated weeds somewhat better than shortleaf pine.

Effects on Foliar Nutrients

Foliage for tissue analysis was collected in August from branches in the upper one-third of tree crowns. Three or more trees from each treatment plot were sampled. Collections were dried for 48 hours at $75{ }^{\circ} \mathrm{C}$ and ground with a UDY Cyclone Sample Mill (UDY Corporation, 201 Rome Court, Fort Collins, C0 80524). Analyses were done by the Soil Testing and Plant Analys is Laboratory, 2400 College Station Road, Athens, GA 30605.

Generally, foliage from trees growing in sludge plots contained more $N, P$, and $Z n$ than that from trees on fertilizer plots (tables 21 through 28). $\mathrm{Ca}$ and $\mathrm{Mg}$ were usually higher in foliage from trees in fertilizer plots. Manganese concentrations were several orders of magnitude higher in foliage from trees grown in the Copper. Basin than in foliage from trees in the other studies reported here.

\section{DISCUSSION}

The heaviest rate of sludge applied in any of the studies was $68 \mathrm{Mg} / \mathrm{ha}$. The primary interest in these data therefore is for use of sewage sludge as fertilizer rather than heavy applications that might be made when disposal on land is the primary goal. While there is no doubt that much heavier amounts of most sludges can be applied in the Southeast with no deleterious effects, one would not expect any increased rate of growth of trees by applying amounts greater than about $34 \mathrm{Mg} / \mathrm{ha}$. Sludge applications of $275 \mathrm{Mg} / \mathrm{ha}$, applied in a nursery experiment (Berry and Marx 1976) had no significant deleterious effect on growth of loblolly or shortleaf pine seediings or on mycorrhizal formation. It is conceivable, however, that heavy applications of some sludyes that are high in salts or heavy metals could innibit growth and mycorrhizal formation (Berry 1985a). At any rate, care should be taken not to exceed State and Federal guidelines on application of heavy metals to soil or on contamination of ground water with nitrates.

In Study 8, an attempt was made to apply equal amounts of plant nutrients in sludge and fertilizer treatments. As is evident from growth data (table 19), the attempt was unsuccessful. Even though analyses found only nitrogen to be higher on sludge plots and all elements in good supply on fertilizer plots, growth was better on sludge plots. Since most of the nutrients in sludge are in organic form, they become available slowly. All nutrients in most fertilizers used in forestry are water soluble and subject to washing and leaching. Therefore it is impractical to apply much over $1120 \mathrm{~kg} / \mathrm{ha}$ of 10-10-10 (112 $\mathrm{kg} / \mathrm{ha}$ of $\mathrm{N}$ ) in a single application. The effect of leaching of fertilizer was demonstrated in the subsoiling study (Study 3 ) in which growth of trees during the first 4 years in fertilizer plots was faster on plots subsoiled to only $46 \mathrm{~cm}$ than on plots subsoiled to 92 $\mathrm{cm}$, a depth which was more conducive to washing and leaching. Subsoiling to a $92-\mathrm{cm}$ depth produced the fastest growth when sludge was the amendment because moisture relations were better and the nutrients, which were in organic form, were not being leached. Split applications of fertilizer are common in agriculture, but in most cases this approach is impractical with forest trees.

Three of the plantings are now 10 years old or older (Studies 1, 2, and 6). In each case, growth of trees on the sludge plots is excellent and appears to be accelerating. In studies comparing a no-amendment control with 
fertilizer and sludge treatments, trees on fertilizer plots are not growing much better than those on control plots (Studies 1, 4, 5, 7, and 8).

It has become apparent in recent years that sludge application and incorporation followed by subsoiling will convert the most unproductive site imaginable into a site as productive as the best undisturbed site in the vicinity. Trees on the sludye plots in the Copper Basin and in the borrow pits are growing very well. Previous treatments that did not include sludge (or subsoiling)

failed. Metz and others (1970) found 670 to $900 \mathrm{~kg} / \mathrm{ha}$ of $\mathrm{N}, 15$ to $22 \mathrm{~kg} / \mathrm{ha}$ of $P$, and 62 to $108 \mathrm{~kg} / \mathrm{ha}$ of $K$ in the forest floor and the upper $7.6 \mathrm{~cm}$ of mineral soil in 20-year-old southern pine plantations. A sludge application of 34 $\mathrm{Mg} / \mathrm{ha}$ at 2 percent $N, 1$ percent $P$, and 0.5 percent $K$ is equivalent to $680 \mathrm{~kg} / \mathrm{ha}$ of $N, 340 \mathrm{~kg} / \mathrm{ha}$ of $P$, and $170 \mathrm{~kg} / \mathrm{ha}$ of $k$. Theoretically, the addition of these organically bound, slow-release nutrients should transform the nutrient status of the most barren site to that of an average undisturbed southern pine plantation. Thus, such a treatment appears to be more than adequate for mere reclamation. It promises to enable restoration of a severely devastated site to the status of a fully productive forest.

Trees growing on sludge-amended plots have produced an average of about 8 percent more wood as a percentage of total-tree weight, with proportionately less foliage, than trees on plots amended with inorganic fertilizer (McNab and Berry 1985).

Foliar analyses confirm the value of sludge as a soil amendment. They show elevated nitrogen and phosphorus in foliage from sludge plots compared with that from fertilizer plots. Wells and Allen (1985) discuss the use of foliar analysis for identification of sites where a benefit can be obtained from application of fertilizer. Elevated Mn in foliage from the Copper Basin suggests Mn toxicity as a possible explanation for the somewhat slower growth rate of trees in that area than on sludgeamended borrow pits. Although soil Mn is higher on two other sites, soil $\mathrm{pH}$ is lowest in the Copper Basin, creating a situation more conducive for Mn uptake. High velocity drying winds also contribute to reduced growth in the Copper Basin Berry 1982; Hursh 1948).

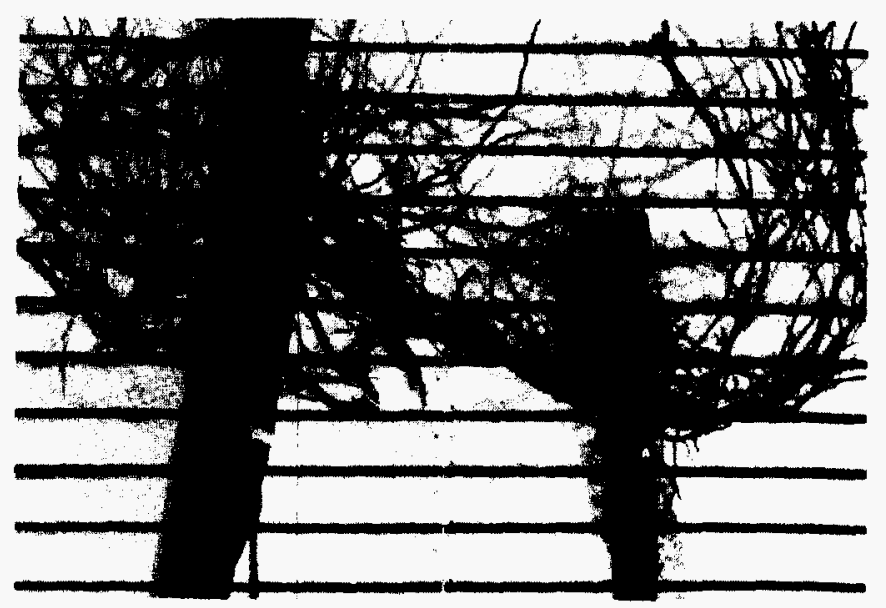

Figure 7.--Root system of tree from a borrow pft not subsolled (left) compared with root system from a borrow pit subsoiled to $0.92 \mathrm{~m}$.

The value of subsoiling for growing trees in hard or compacted soil cannot be overstated. In observations made during the subsoiling study (Study 3 ), roots of loblolly pine were found to penetrate the full depth of $92 \mathrm{~cm}$ in a subsoiled trench within 2 years. Roots did not penetrate the soil on this site, if it had not been previously loosened (fig. 7). Even on a yood site with deep, rich Oranyeburg soil, subsoiling increased early growth. Al though increasing the depth from 46 to $92 \mathrm{~cm}$ (table 13) or the number of directions from one (parallel lines) to two (creating a grid) did not produce faster growth at 7 years, any degree of subsoiling was significantly better than disking alone. Another advantage observed but not measured in this work was the excellent moisture retention on recently subsoiled plots during rains. One of the most important benefits of subsoiling borrow pits or other extremely hard areas, however, probably will not be seen until the trees are much older 
and larger. It is believed and observations indicate (fig. 8) that trees growing without the benefit of deep subsoiling will be more prone to windthrow than trees growing on plots that have been subsoiled. All subsoiling in these studies was done with readily available ripping shanks with no special shapes or modifications.

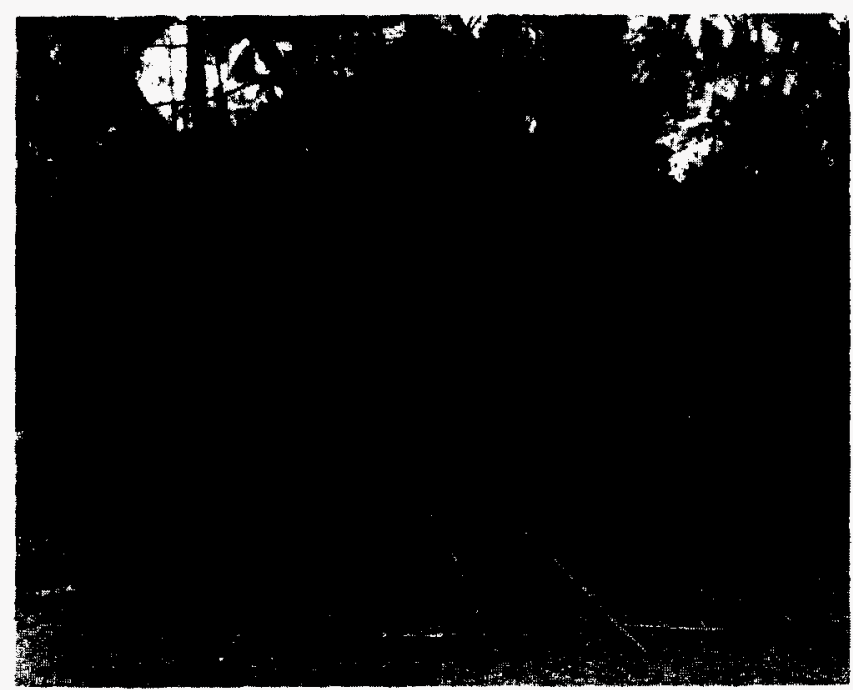

Figure 8.--Trees planted in hard material not subsoiled can be extremely shallow rooted and prone to windthrow.

The use of herbaceous groundcover in conjunction with trees may sometimes have dubious value. Quick stabilization of soil is important, and where fertilizer is being used, groundcover helps capture water-soluble nutrients that might otherwise be lost from the site. Dense herbaceous vegetation, however, competes strongly with tree seedlings for water and nutrients. The best growth of herbaceous plants is usually achieved at a higher $\mathrm{pH}$ than what is best for pines. Therefore a quick herbaceous

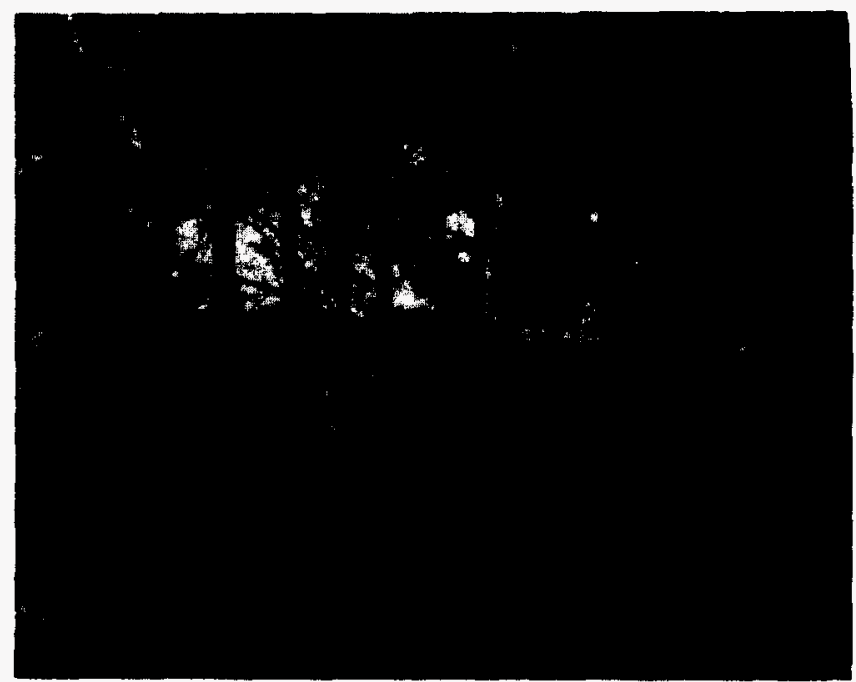

Figure 9.--Trees planted at close spacing in subsolled furrows that follow contours control erosion effectively without groundcover.

yroundcover must be bought at a price of slower growth of trees. Runoff can be controlled to a large extent by subsoiling on the contour and by planting trees at a close spacing in the furrows (fig. 9). The rows could be spaced normally at $2.44 \mathrm{~m}$ or more and trees spaced at $1.22 \mathrm{~m}$ within rows.

If sludge is used instead of fertilizer, plant nutrients will be retained on the site because they are released slowly. If weed seeds are present on the site, weed growth will be stimulated by sludge, often to an extent that inhibits growth of tree seedlings. If such a situation can be foreseen, attempts should be made to control weeds, even if tree planting must be delayed a year.

Society is obliged to dispose of sewage sludge by the most environmentally sound means possible. Disposal by application on disturbed sites can result in superior reclamation. Even on nigh-quality forest sites, judicious disposal of some sludges will promote growth of trees with no deleterious effects. 


\section{Literature Cited}

Berry, C.R. 1985a. Growth and heavy metal accumulation in pine seedlings grown with sewage sludge. Journal of Environmenta) Quality 14(3):415-419.

Berry, C.R. 1985b. Subsoiling and sewage sludge aid loblolly pine establishment on adverse sites. Reclamation and Revegetation Research 3:301-311.

Berry, Charles R. 1977. Initial response of pine seedlings and weeds to dried sewage sludge in rehabilitation of an eroded forest site. Res. Note SE-249. Asheville, NC: U.S. Department of Agriculture, Forest Service, Southeastern Forest Experiment Station. $8 \mathrm{pp}$.

Berry, Charles R. 1979a. Slit application of fertilizer tablets and sewage sludge improve initial growth of loblolly pine seedlings in the Tennessee Copper Basin. Reclamation Review 2:33-38.

Berry, Charles R. 1979b. Subsoiling improves growth of pine on a Georgia Piedmont site. Res. Note SE-284. Asheville, NC: U.S. Department of Agriculture, Forest Service, Southeastern Forest Experiment Station. $3 \mathrm{pp}$.

Berry, Charles R. 1982. Dried sewage sludge improves growth of pines in the Tennessee Copper Basin. Reclamation and Revegetation Research 1:195-201.

Berry, Charles R. 1983. Growth response of four hardwood tree species to spot fertilization by nutrient tablets in the Tennessee Copper Basin. Reclamation and Revegetation Research 2:167-175.

Berry, Charles R.; Marx, Donald H. 1976. Sewage sludge and Pisolithus tinctorius ectomycorrhizae: their effect on growth of pine seedlings. Forest Science 22:351-358.

Berry, Charles R.; Marx, Donald H. 1977. Growth of loblolly pine seedlings in strip-mined kaolin spoil as influenced by sewage sludge. Journal of Environmental Quality 6(4):379-381.

Berry, Charles R.; Marx, Donald H. 1980. Significance of various soil amendments to borrow pit reclamation with loblolly pine and fescue. Reclamation and Revegetation Research 3:87-94.

Bitton, G.; Damron, B.L.; Edds, G.R.; Davidson, J.M. eds. 1980. Sludge - health risks of land application. Proceedings of the workshop; 1980 April 29May 1; Tampa, FL. Ann Arbor, MI: Ann Arbor Science Publishers, Inc./The Butterworth Group. 367 pp.

Bledsoe, Caroline S., ed. 1981. Muntcipal sludge application to Pacific Northwest forest lands. Proceedings, symposium; 1980 July 8-10; Seattle, WA: College of Forest Resources, University of Washington, $155 \mathrm{pp}$.

Cole, Dale W.; Henry, Charles L.; Nutter, Wade L., eds. 1986. The forest alternative for treatment and utflization of municipal and industrial wastes. Proceedings, symposium on forest land applications: 1985 June 25-28; Seattle, MA: College of Forest Resources, University of Washington. $582 \mathrm{pp}$.
Elliott, L.F.; Stevenson, F.J., eds, 1977. Soils for management of organic wastes and waste waters. Proceedings, symposium; 1975 March 11-13; Muscle Shoals. AL. Madison, WI: Soll Science Society of America, American Society of Agronomy, and Crop Science Society of America. 650 pp.

Hatchell, G.E.; Berry, C.R.; Muse, H.D. 1985. Nondestructive indices related to aboveground biomass of young loblolly and sand pines on ectomycorrhizal and fertilizer plots. Forest Science 31:419-427.

Hinkle, K.R. 1982. Use of municipal sludge in the reclamation of abandoned pyrite mines in Virginia. PP. 421-432. In: Sopper, W.E.; Seaker, E.M.; Bastian, R.K., eds. Utilization of muntcipal wastewater and sludge for land reclamation and biomass production. University Park, PA: Pennsylvania State University Press.

Hursh, C.R. 1948. Local climate in the Copper Basin of Tennessee as modified by the removal of vegetation. CirC. 774. Washington, OC: U.S. Department of Agriculture. $38 \mathrm{pp}$.

Kormanik, Paul P.; Schultz, Richard C. 1985. Significance of sewage sludge amendments to borrow pit reclamation with sweetgum and fescue. Res. Note SE-329. Asheville, NC: U.S. Department of Agriculture, Forest Service, Southeastern Forest Experiment Station. $7 \mathrm{pp}$.

May, J.T. 1977. Highlights of a decade of research and reclamation on kaolin clay strip mining spoil, 1966-1976. Ga. For. Res. Rep. 37. Macon: Georgia Forest Research Counctl. 36 pp.

McCalla, T.M.; Peterson, J.R.; Lue-Hing, C. 1977. Properties of agricuitural and municipal wastes. pp. 10-43. In: Elliott, L.F.; Stevenson, F.J., eds. Proceedings, symposium; Soils for management of organic wastes and waste waters; 1975 March 11-13; Muscle Shoals, AL. Madison, Wl: Soll Science Society of America, American Society of Agronomy, and Crop Science Society of America.

McKee, W.H., Jr.; McLeod, K.W.; Davis, C.E.; McKevlin, M.R.; Thomas, H.A. 1986. Growth response of loblolly pine to municipal and industrial sewage sludge applied at four ages on upper coastal plain sites. pp. 272-281. In: Cole, Dale H.; Henry, Charles L.; Nutter, Wade L., eds. The forest alternative for treatment and utilization of municipal and industrial wastes. Seattle, WA: University of Washington Press.

McNab, W. Henry; Berry, Charles R. 1985. Distribution of aboveground blomass in three pine species planted on a devastated site amended with sewage sludge or inorganic fertilizer. Forest Science 31:373-382.

Metz, Louis J.; Wells, Carol G.; Kormanik, Paul P. 1970. Comparing the forest floor and surface soil beneath four pine species in the Virginia Pledmont. Re5. Pap. SE-55. Asheville, NC: U.S. Department of Agriculture, Forest Service, Southeastern Forest Experiment Station, $8 \mathrm{pp}$. 
National Association of State Universities and LandGrant Colleges. Recycling anicipal sludge and effluents on land. Proceedings, joint conference; 1973 July 9-13; Champaign, IL. Washington, DC: National Association of State Universities and Land-Grant Colleges. 242 pp.

Page, A.L.; Gleason, Thomas L., III; Smith, James E., Jr.; Iskandar, I.K.; Somers, L.E., eds. 1983. Proceedings of a workshop; Utilization of municipal wastewater and sludge on land. Riverside, $C A$ : University of California. $480 \mathrm{pp}$.

Ruehle, John L. 1980. Growth of containerized loblolly pine with specific ectomycorrhizae after 2 years on an amended Dorrow pit. Reclamation Review $3: 95-101$.

Schaller, Frank W.; Sutton, Paul, eds, 1978. Reclamation of drastically disturbed lands. Proceedings, symposium; 1976 August 9-12; Wooster, $\mathrm{OH}$. Madison, WI: American Society Agronomy, Crop Science Society of America, and Soil Science Society of America. $742 \mathrm{pp}$.

Sopper, William E.; Kardos, Louis T., eds. 1973. Recycling treated municipal wastewater and sludge through forest and cropland. Proceedings, symposium; University Park, PA: Pennsylvania State University Press. $479 \mathrm{pp}$.

Sopper, William E.; Kerr, Sonja N., eds. 1979. Utilization of municipal sewage effiuent and sludge on forest and disturbed land. Proceedings, symposium; 1977 March 21-23; Chicago, IL. University Park, PA: Pennsylvania State University Press. 537 pp.
Sopper, William E.; Seaker, Eileen M. 1983. A guide for revegetation of mined land in Eastern United States using municipal sludge. University Park, PA: School of Forest Resources and Institute for Research on Land and Water Resources, Pennsylvania State University. $93 \mathrm{pp}$.

Sopper, Milliam E.; Seaker, Eileen M.; Bastian, Robert K., eds. 1982. Land reclamation and biomass production with municipal wastewater and sludge. Proceedings, symposium on Utilization of municipal wastewater and sludge for land reclamation and biomass production; 1980 September 16-18, Pittsburgh, PA. University Park, PA: Pennsylvania State Unfversity Press. $524 \mathrm{pp}$.

Vogel, Willis 6.1981 . A guide for revegetating coal minesolls in the Eastern United States. Gen. Tech. Rep. NE-68. Broomal1, PA: U.S. Department of Agriculture, Forest Service, Northeastern Forest Experiment Station. $190 \mathrm{pp}$.

Wells, Carol; Allen, Lee. 1985. When and where to apply fertilizer. A loblolly pine management guide, Gen. Tech. Rep. SE-36. Asheville, NC: U.S. Department of Agriculture, Forest Service, Southeartern Forest Experiment Station. 23 pp.

Wells, C.G.; McLeod, K.H.; Murphy, C.E.; Jensen, J.R.; Corey, J.C.; MCKee, H.H.; Christensen, E.J. 1985. Response of loblolly pine plantations to two sources of sewage sludge. PP. 85-94. TAPPI [Technical Association of the Pulp and Paper Industry]; At lanta, GA: TAPPI Press. 


\section{TABLES}

Table 1.--Chemical analysis of sludges employed in eight field studies

\begin{tabular}{|c|c|c|c|}
\hline \multirow[b]{3}{*}{ Element } & \multicolumn{3}{|c|}{ Sludge } \\
\hline & \multicolumn{2}{|c|}{ Athens } & \multirow[b]{2}{*}{ Macon } \\
\hline & Fresh & 01d & \\
\hline & $-\cdots$ & -- & $-\cdot-$ \\
\hline N & 2.0 & 1.0 & 1.8 \\
\hline$P$ & 0.65 & 0.13 & 0.71 \\
\hline K & 0.05 & 0.04 & 0.02 \\
\hline $\mathrm{Ca}$ & 0.84 & 0.62 & - \\
\hline $\mathrm{Mg}$ & 0.11 & 0.06 & 0.03 \\
\hline $\mathrm{Al}$ & 0.90 & 0.36 & - \\
\hline \multirow[t]{2}{*}{$\mathrm{Fe}$} & 0.58 & 0.33 & 0.01 \\
\hline & -- & --- & $-\cdots$ \\
\hline$B a$ & 12.0 & 27.7 & -- \\
\hline$B$ & 15.5 & 8.4 & - \\
\hline $\mathrm{Cd}$ & 5.9 & 4.5 & -- \\
\hline Co & 25.0 & 13.2 & - \\
\hline $\mathrm{Cr}$ & 40.3 & 28.6 & -- \\
\hline $\mathrm{Cu}$ & 153.3 & 115.4 & -- \\
\hline$M n$ & 231.0 & 52.0 & 93.0 \\
\hline Mo & 9.0 & 2.2 & -- \\
\hline $\mathrm{Na}$ & 121.0 & 23.0 & - \\
\hline $\mathrm{Ni}$ & 13.1 & 9.8 & -- \\
\hline $\mathrm{Pb}$ & 43.7 & 34.6 & -- \\
\hline$S r$ & 41.9 & 10.4 & -- \\
\hline $\mathrm{Zn}$ & 806.0 & 505.0 & 53.0 \\
\hline
\end{tabular}




\begin{tabular}{|c|c|c|c|c|c|c|c|c|c|c|c|c|c|}
\hline $\begin{array}{l}\text { Study } \\
\text { number }\end{array}$ & $\begin{array}{c}\text { Type } \\
\text { of soil }\end{array}$ & $\begin{array}{c}\text { Total } \\
N\end{array}$ & $\begin{array}{c}\text { Available } \\
P\end{array}$ & $\underline{K}$ & $\mathrm{Mg}$ & $\mathrm{Ca}$ & Mn & $\mathrm{pH}$ & CEC & $\begin{array}{l}\text { Organic } \\
\text { matter }\end{array}$ & Mecha & $\frac{i c a l}{\text { silt }}$ & $\frac{\text { analysis }}{\text { Clay }}$ \\
\hline & & $-\cdots$ & $\cdots-\cdot$ & - & $/ \mathrm{m}-$ & - & -- & \multicolumn{2}{|c|}{ meq $/ 100 \mathrm{~g}$} & $-\cdots$ & --- & -- & $-\cdots$ \\
\hline 1 & $\begin{array}{l}\text { Borrow pit } \\
(\text { BP-la) }\end{array}$ & 174 & 2 & 29 & 16 & 29 & 2 & 4.58 & 1.72 & 0.1 & 81 & 2 & 17 \\
\hline 2 & $\begin{array}{l}\text { Borrow pit } \\
\text { (BP-lb) }\end{array}$ & 102 & 2 & 33 & 21 & 65 & 2 & 4.59 & 1.29 & 0.3 & 81 & 2 & 17 \\
\hline 3 & $\begin{array}{l}\text { Borrow pit } \\
(B P-2)\end{array}$ & 99 & 4 & 41 & 56 & 127 & 5 & 4.81 & 2.14 & 0.4 & 79 & 2 & 19 \\
\hline 4 & $\begin{array}{l}\text { Borrow pit } \\
(B P-3)\end{array}$ & 84 & 3 & 35 & 38 & 106 & 2 & 4.82 & 1.73 & 0.3 & 73 & 2 & 25 \\
\hline 5 & Kaolin spoil' & 35 & 3 & 21 & 55 & 153 & -- & 6.19 & 1.49 & 0.1 & 93 & 2 & 5 \\
\hline 6 & $\begin{array}{l}\text { Hayesville, } \\
\text { severely } \\
\text { eroded }\end{array}$ & 78 & 3 & 7 & 3 & 3 & 15 & 4.40 & 1.62 & 0.1 & .67 & 15 & 18 \\
\hline 7 & Orangeburg & 238 & 31 & 47 & 17 & 111 & 22 & 4.96 & 2.78 & 1.6 & 92 & 5 & 3 \\
\hline 8 & $\begin{array}{l}\text { Dothan } \\
\text { and Norfolk }\end{array}$ & 397 & 8 & 51 & 35 & 144 & 6 & 4.97 & 3.92 & 1.8 & 92 & 6 & 2 \\
\hline
\end{tabular}

'Samples collected after application of lime; analyses of adjacent unlimed areas have shown a $\mathrm{pH}$ of 4.4 to 5.1 , $\mathrm{Ca}$ of 60 to $100 \mathrm{p} / \mathrm{m}, \mathrm{Mg}$ of $20 \mathrm{p} / \mathrm{m}$. 
Table 3.--Soil chemical properties on a borrow pit (BP-la, Study 1) 10 years after addition of amendments and being planted with loblolly pine?

\begin{tabular}{|c|c|c|c|c|c|c|c|c|}
\hline Treatment & $N$ & $P$ & $K$ & $\mathrm{Ca}$ & $\mathrm{Mg}$ & $0 . M$. & $\mathrm{pH}$ & CEC \\
\hline & - & - & $-p / m$ & -- & - & $\underline{\%}$ & & meq/100 g \\
\hline Sludye ${ }^{2}$ & $390 a$ & $5 b a$ & $49 a$ & $76 b$ & $22 a$ & $1.3 \mathrm{a}$ & $4.30 \mathrm{~b}$ & $4.4 a$ \\
\hline Fertilizer 3 & $142 b$ & $2 b$ & $35 b$ & $103 a$ & $59 a$ & $0.5 b$ & $4.90 \mathrm{a}$ & $1.9 b$ \\
\hline Control & $174 \mathrm{D}$ & $2 b$ & $30 \mathrm{~b}$ & $29 c$ & $17 \mathrm{~b}$ & $0.3 b$ & $4.54 a b$ & $1.5 b$ \\
\hline
\end{tabular}

'Within columns, means followed by the same letter do not differ significantly at $\underline{P}=0.05$.

$234 \mathrm{Mg} / \mathrm{ha}$.

$3560 \mathrm{~kg} / \mathrm{ha}$ of $10-10-10$ fertilizer plus $2240 \mathrm{~kg} / \mathrm{ha}$ of dolomitic lime.

Table 4.--Growth of loblolly pine after 10 years on a borrow pit (BP-1a, Study 1) as influenced by sewage sludge and fertilizer'

\begin{tabular}{lccc}
\hline Treatment & Height & Diameter & $\mathrm{D}^{2} \mathrm{H}$ \\
\hline & $\mathrm{cm}$ & $\mathrm{mm}$ & $\frac{\mathrm{cm}^{3}}{10,000)}$ \\
Sludge $^{2}$ & $979 \mathrm{a}$ & $154 \mathrm{a}$ & $248 \mathrm{a}$ \\
Fertilizer $^{3}$ & $454 \mathrm{~b}$ & $68 \mathrm{~b}$ & $31 \mathrm{~b}$ \\
Control & $265 \mathrm{c}$ & $41 \mathrm{~b}$ & $18 \mathrm{~b}$ \\
\hline
\end{tabular}

1Within columns, means followed by the same letter do not differ significantly at $\underline{P}=0.05$.

$234 \mathrm{Mg} / \mathrm{ha}$.

$3560 \mathrm{~kg} / \mathrm{ha}$ of $10-10-10$ fertilizer plus $2240 \mathrm{~kg} / \mathrm{ha}$ of dolomitic lime. 
Table 5.--Soil chemical properties on a borrow pit (BP-1b, Study 2) 10 years after addition of amendments and planted to sweetgum 1

\begin{tabular}{|c|c|c|c|c|c|c|c|c|}
\hline $\begin{array}{c}\text { Treatment } \\
(\mathrm{Mg} / \mathrm{ha})\end{array}$ & $\mathrm{N}$ & $P$ & $K$ & $\mathrm{Ca}$ & $\mathrm{Mg}$ & $0 . M$. & $\mathrm{pH}$ & CEC \\
\hline & - & - & $-p / n$ & - & -- & $\underline{q}$ & & meg/100 g \\
\hline 0 & $102 b$ & $2 c$ & $33 b$ & $65 a$ & $21 a$ & $0.3 c$ & $4.59 a$ & $1.3 c$ \\
\hline 17 & $368 a$ & $26 b$ & $47 a$ & $65 a$ & $17 a$ & $0.9 b$ & $4.35 b$ & $5.6 b$ \\
\hline 34 & $492 a$ & $43 b$ & $46 a$ & $58 a$ & $15 a$ & $1.3 a$ & $4.21 \mathrm{~b}$ & $7.9 a$ \\
\hline 68 & $596 a$ & $72 a$ & $52 a$ & $76 a$ & $21 a$ & $1.4 a$ & $4.20 \mathrm{~b}$ & $7.9 a$ \\
\hline
\end{tabular}

'Within columns, means followed by the same letter do not differ significantly at $\underline{P}=0.05$.

Table 6.--Growth of sweetgum after 10 years on a borrow pit (BP-1b, Study 2) amended with sewage sludge!

\begin{tabular}{|c|c|c|c|}
\hline & $\underline{m}$ & $\mathrm{~cm}$ & $\begin{array}{r}\mathrm{cm}^{3} \\
\times \quad 10,000) \\
\end{array}$ \\
\hline 0 & $0.63 c$ & $3.6 \mathrm{~b}$ & $0.2 \mathrm{c}$ \\
\hline 17 & $4.11 b$ & $8.6 a$ & $3.6 b$ \\
\hline 34 & $5.49 a$ & $10.6 \mathrm{a}$ & $7.1 \mathrm{a}$ \\
\hline 68 & $5.57 \mathrm{a}$ & $10.8 \mathrm{a}$ & $7.4 a$ \\
\hline
\end{tabular}

'Within columns, means followed by the same letter do not differ significantly at $\underline{P}=0.05$. 
Table 7.--Soil chemical properties of a borrow pit (BP-2, Study 3) used to test effects of subsoiling treatments on loblolly pine 7 years after amendments were applied'

\begin{tabular}{|c|c|c|c|c|c|c|c|c|}
\hline Treatment & N & $P$ & $k$ & $\mathrm{Ca}$ & $\mathrm{Mg}$ & O.M. & $\mathrm{pH}$ & CEC \\
\hline & - - & - & $\mathrm{p} / \mathrm{m}$ & - & - & $\underline{\%}$ & & $\mathrm{meq} / 100 \mathrm{~g}$ \\
\hline Sludge 2 & $219 a$ & $44 a$ & $32 b$ & $124 a$ & $22 b$ & $0.8 a$ & $4.25 b$ & $6.2 a$ \\
\hline Fertilizer 3 & $99 b$ & $4 b$ & $41 \mathrm{a}$ & $127 a$ & $56 a$ & $0.4 b$ & $4.81 \mathrm{a}$ & $2.1 b$ \\
\hline
\end{tabular}

'Within columns, means followed by the same letter do not differ significantiy
at $\underline{P}=0.05$.

$217 \mathrm{Mg} / \mathrm{ha}$.

${ }^{3} 1120 \mathrm{~kg} / \mathrm{ha}$ of $10-10-10$ fertilizer plus $2240 \mathrm{~kg} / \mathrm{ha}$ of dolomitic $1 \mathrm{ime}$. 
Table 8.--Influence of subsoiling on growth of loblolly pine on a borrow pit (BP-2, Study 3) amended with sewage sludge or fertilizer after 7 years 1

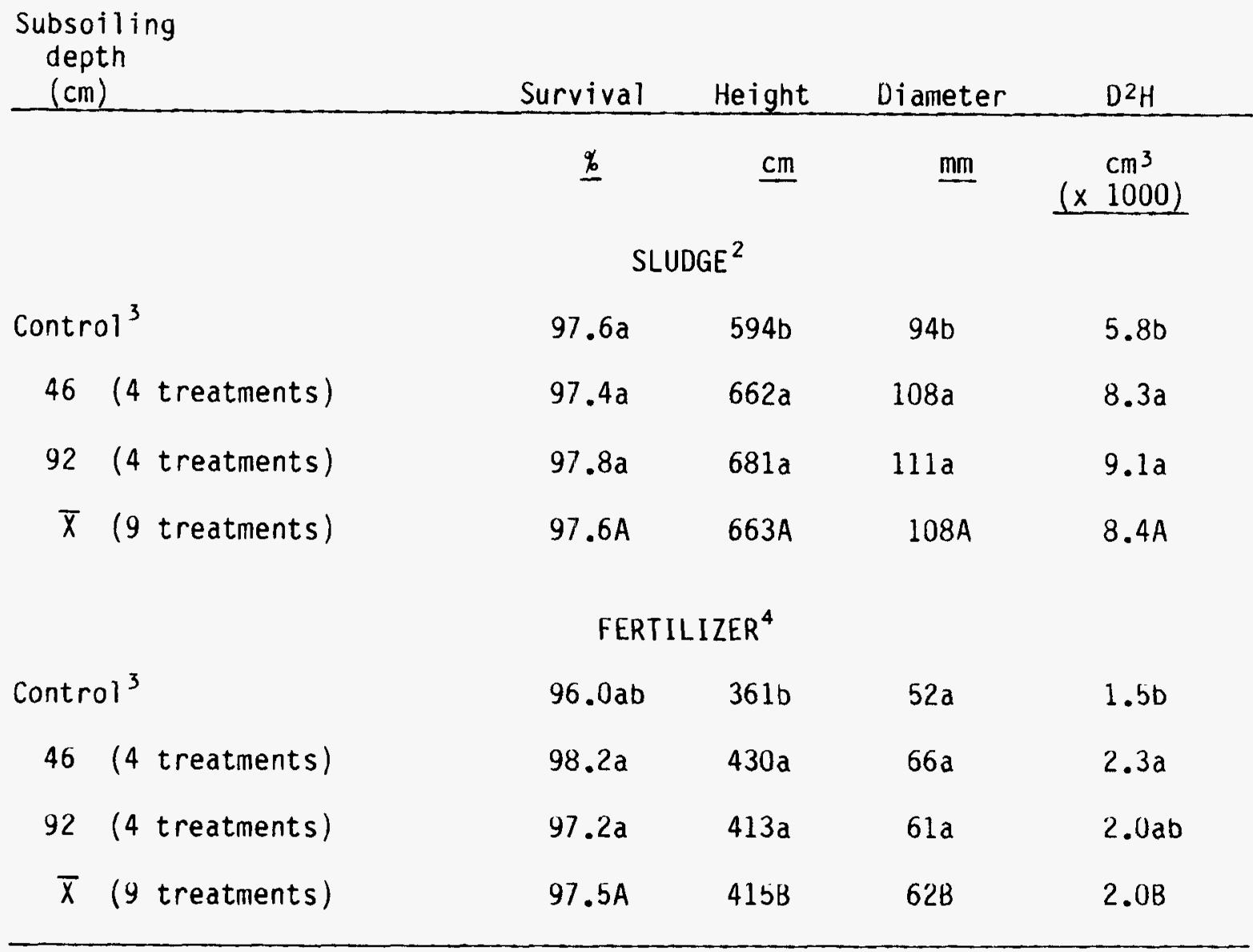

'Within columns, means followed by the same lowercase or uppercase letter do not differ significantly at $\underline{P}=0.05$.

$217 \mathrm{Mg} / \mathrm{ha}$.

${ }^{3}$ Disk only, approximately $15 \mathrm{~cm}$ in depth.

${ }^{4} 1120 \mathrm{~kg} / \mathrm{ha}$ of $10-10-10$ fertilizer plus $2240 \mathrm{~kg} / \mathrm{ha}$ of dolomitic lime. 
Table 9.--Soil chemical properties on a borrow pit (BP-3, Study 4) planted with hardwoods and loblolly pine 4 years after addition of amendments 1

\begin{tabular}{|c|c|c|c|c|c|c|c|c|}
\hline Treatment & $\mathrm{N}$ & $P$ & $k$ & $\mathrm{Ca}$ & $\mathrm{Mg}$ & $0 . M$. & pH & CEC \\
\hline & - & -- & $\mathrm{p} / \mathrm{n}$ & & 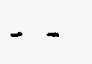 & $\underline{\underline{z}}$ & & meq/100 y \\
\hline Sludge 2 & $302 a$ & $69 a$ & $37 b$ & $199 a$ & $41 b$ & $1.9 a$ & $4.73 b$ & $5.6 a$ \\
\hline Fertilizer 3 & $122 \mathrm{D}$ & $5 b$ & $61 a$ & $187 a$ & $86 a$ & $1.2 a b$ & $5.25 a$ & $5.4 a$ \\
\hline Control & $84 \mathrm{~b}$ & $3 b$ & $35 b$ & $106 \mathrm{~b}$ & $38 b$ & $0.7 \mathrm{~b}$ & $4.82 b$ & $3.5 b$ \\
\hline
\end{tabular}

'Within columns, means followed by the same letter do not differ significantly at $\underline{p}=0.05$.

${ }^{2} 68 \mathrm{Mg} / \mathrm{ha}$.

${ }^{3} 1120 \mathrm{~kg} / \mathrm{ha}$ of $10-10-10$ fertilizer plus $2240 \mathrm{~kg} / \mathrm{ha}$ of dolomitic lime.

Table 10.--A comparison of growth of six tree species on borrow pit plots (BP-3, Study 4) after 4 years amended with sewage sludge or fertilizer'

\begin{tabular}{|c|c|c|c|c|}
\hline Species & Survival & Height & Diameter & $\mathrm{D}^{2} \mathrm{H}$ \\
\hline & $\underline{10}$ & $\underline{\mathrm{cm}}$ & $\underline{\mathrm{mm}}$ & $\begin{array}{c}\mathrm{cm}^{3} \\
\times \quad 10,000) \\
\end{array}$ \\
\hline \multicolumn{5}{|c|}{ SLUDGE $^{2}$} \\
\hline $\begin{array}{l}\text { Loblolly } \\
\text { Sycamore } \\
\text { Sawtooth oak } \\
\text { Green ash } \\
\text { Sweetgum } \\
\text { Yellow-poplar }\end{array}$ & $\begin{array}{l}87.2 \mathrm{a} \\
83.6 \mathrm{a} \\
79.2 \mathrm{a} \\
99.6 \mathrm{a} \\
94.0 \mathrm{a} \\
40.8 \mathrm{~b}\end{array}$ & $\begin{array}{l}329 a b \\
375 a \\
222 c \\
277 b c \\
268 b c \\
198 c\end{array}$ & $\begin{array}{r}111 a \\
57 b \\
54 b \\
52 b \\
47 b \\
37 b\end{array}$ & $\begin{array}{l}4.58 a \\
2.31 b \\
0.78 b \\
0.950 \\
0.89 b \\
0.99 b\end{array}$ \\
\hline \multicolumn{5}{|c|}{ FERTILIZER ${ }^{3}$} \\
\hline $\begin{array}{l}\text { Loblolly } \\
\text { Sycamore } \\
\text { Sawtooth oak } \\
\text { Green ash } \\
\text { Sweetgum } \\
\text { Yellow-poplar }\end{array}$ & $\begin{array}{l}92.8 a \\
86.8 a b \\
85.6 a b \\
96.8 a \\
95.6 a \\
72.0 b\end{array}$ & $\begin{array}{l}278 a \\
217 b \\
144 c \\
132 c \\
129 c \\
77 d\end{array}$ & $\begin{array}{l}86 a \\
35 b \\
37 b \\
24 c \\
21 c d \\
16 d\end{array}$ & $\begin{array}{l}2.30 a \\
0.34 b \\
0.21 b \\
0.10 b \\
0.08 b \\
0.03 b\end{array}$ \\
\hline
\end{tabular}

'Within columns and amendments, means followed by the same letter do not differ significantly at $\underline{P}=0.05$.

${ }^{2} 68 \mathrm{Mg} / \mathrm{ha}$.

${ }^{3} 1120 \mathrm{~kg} / \mathrm{ha}$ of $10-10-10$ fertilizer plus $2240 \mathrm{~kg} / \mathrm{ha}$ of dolomitic lime. 
Table 11.--Growth of three tree species on a borrow pit (BP-3, Study 4) after 4 years on plots amended with sludge or fertilizer compared with growth on nonamended control plots'

\begin{tabular}{|c|c|c|c|c|}
\hline Treatment & Survival & Height & Diameter & $\mathrm{D}^{2} \mathrm{H}$ \\
\hline & $\underline{\psi}$ & $\underline{\mathrm{cm}}$ & $\underline{\mathrm{mm}}$ & $\begin{array}{c}\mathrm{cm}^{3} \\
(\times \quad 10,000) \\
\end{array}$ \\
\hline \multicolumn{5}{|c|}{ GREEN ASH } \\
\hline $\begin{array}{l}\text { Sludye } 2 \\
\text { Fertilizer } 3 \\
\text { Control }\end{array}$ & $\begin{array}{l}99.6 a \\
96.8 a b \\
93.2 b\end{array}$ & $\begin{array}{r}277 a \\
132 b \\
79 c\end{array}$ & $\begin{array}{l}54 a \\
24 b \\
14 c\end{array}$ & $\begin{array}{l}0.95 a \\
0.10 b \\
0.02 b\end{array}$ \\
\hline \multicolumn{5}{|c|}{ SWEETGUM } \\
\hline $\begin{array}{l}\text { Sludge } 2 \\
\text { Fertilizer } 3 \\
\text { Control }\end{array}$ & $\begin{array}{l}94.0 a \\
95.6 a \\
96.8 a\end{array}$ & $\begin{array}{r}268 a \\
129 b \\
80 b\end{array}$ & $\begin{array}{l}47 a \\
21 b \\
14 b\end{array}$ & $\begin{array}{l}0.89 a \\
0.08 a \\
0.02 a\end{array}$ \\
\hline \multicolumn{5}{|c|}{ LOBLOLLY PINE } \\
\hline $\begin{array}{l}\text { Sludge } 2 \\
\text { Fertilizer } \\
\text { Control }\end{array}$ & $\begin{array}{l}87.2 a \\
92.8 a \\
90.8 a\end{array}$ & $\begin{array}{l}329 a \\
278 a \\
197 b\end{array}$ & $\begin{array}{r}111 \mathrm{a} \\
86 \mathrm{~b} \\
62 \mathrm{c}\end{array}$ & $\begin{array}{l}4.58 \mathrm{a} \\
2.30 \mathrm{~b} \\
0.93 \mathrm{~b}\end{array}$ \\
\hline
\end{tabular}

'Within columns and species, means followed by the same letter do not differ significantly at $\underline{P}=0.05$.

${ }^{2} 68 \mathrm{Mg} / \mathrm{ha}$.

${ }^{3} 1120 \mathrm{~kg} / \mathrm{ha}$ of $10-10-10$ fertilizer plus $2240 \mathrm{~kg} / \mathrm{ha}$ of dolomitic lime. 
Table 12.--Soil chemical properties on a kaolin spoil planted with sweetgum (Study 5) 4 years after addition of amendments 1

\begin{tabular}{|c|c|c|c|c|c|c|c|c|}
\hline Treatment & $\mathrm{N}$ & $P$ & K & $\mathrm{Ca}$ & $\mathrm{Mg}$ & O.M. & $\mathrm{pH}$ & CEC \\
\hline & - & - & $-p / m$ & - & -- & $\underline{q}$ & & $\mathrm{meq} / 100 \mathrm{~g}$ \\
\hline Sludge 2 & $795 a$ & $79 a$ & $31 a$ & $379 a$ & $52 a$ & $2.4 a$ & $6.12 a$ & $2.7 \mathrm{a}$ \\
\hline Fertilizer 3 & $75 b$ & $11 b$ & $33 a$ & $165 b$ & $56 a$ & $0.5 b$ & $6.28 a$ & $1.6 \mathrm{~b}$ \\
\hline Control 4 & $35 b$ & $3 c$ & $21 b$ & $153 b$ & $55 a$ & $0.3 b$ & $6.19 a$ & $1.5 b$ \\
\hline
\end{tabular}

Samples collected after application of lime; analyses of adjacent unlimed areas have shown a $\mathrm{pH}$ of 4.4 to 5.1 , Ca of 60 to $100 \mathrm{p} / \mathrm{m}, \mathrm{Mg}$ of $20 \mathrm{p} / \mathrm{m}$, and $\mathrm{K}$ of $24 \mathrm{p} / \mathrm{m}$.

${ }^{1}$ Within columns, means followed by the same letter do not differ significantly at $\underline{P}=0.0 \mathrm{~b}$.

$234 \mathrm{Mg} / \mathrm{ha}$.

${ }^{3} 1120 \mathrm{~kg} / \mathrm{ha}$ of 10-10-10 fertilizer plus $2240 \mathrm{~kg} / \mathrm{ha}$ of dolomitic lime.

${ }^{4} 2240 \mathrm{~kg} / \mathrm{ha}$ of dolomitic lime. 
Table 13.--Growth of sweetgum on a kaolin spoil (Study 5) 4 years after addition of amendments 1

\begin{tabular}{|c|c|c|c|c|}
\hline Treatment & Survival & Height & Diameter & $D^{2} H$ \\
\hline & $\underline{\%}$ & $\mathrm{Cm}$ & $\underline{\mathrm{mm}}$ & $\begin{array}{c}\mathrm{cm}^{3} \\
\times 10,000) \\
\end{array}$ \\
\hline Sludge 2 & $95.0 \mathrm{a}$ & $145 a$ & $26 a$ & $0.14 a$ \\
\hline Fertilizer 3 & $99.3 a$ & $86 b$ & $17 b$ & $0.04 b$ \\
\hline Control 4 & $95.3 a$ & $76 b$ & $17 \mathrm{~b}$ & $0.03 b$ \\
\hline
\end{tabular}

'Within columns, means followed by the same letter do not differ significantly at $\underline{P}=0.05$.

$234 \mathrm{Mg} / \mathrm{ha}$.

${ }^{3} 1120 \mathrm{~kg} / \mathrm{ha}$ of $10-10-10$ fertilizer plus $2240 \mathrm{~kg} / \mathrm{ha}$ of dolomitic lime.

${ }^{4} 2240 \mathrm{~kg} / \mathrm{ha}$ of dolomitic lime.

Table 14.--Soil chemical properties of study plots in the Tennessee Copper Basin planted with three pine species (Study 6) 10 years after addition of amendments'

\begin{tabular}{|c|c|c|c|c|c|c|c|c|}
\hline Treatment & $\mathrm{N}$ & $P$ & $k$ & $\mathrm{Ca}$ & $\mathrm{Mg}$ & $0 . M$. & $\mathrm{pH}$ & CEC \\
\hline & - & -- & $-p / m$ & - & - & $\underline{q}$ & & meq/100 \\
\hline Sludge 2 & $374 a$ & $18 a$ & $64 a$ & $61 \mathrm{a}$ & $14 a$ & $1.0 \mathrm{a}$ & $4.29 b$ & $7.1 a$ \\
\hline Fertilizer 3 & $184 b$ & 1b & $61 a$ & $82 a$ & $15 a$ & $0.3 b$ & $4.67 a$ & $1.4 b$ \\
\hline
\end{tabular}

'Within columns, means followed by the same letter do not differ significantly at $\underline{P}=0.05$.

$234 \mathrm{Mg} / \mathrm{ha}$.

${ }^{3} 896 \mathrm{~kg} / \mathrm{ha}$ of $10-10-10$ fertilizer plus $1417 \mathrm{~kg} / \mathrm{ha}$ of $\mathrm{CaO}$. 
Table 15.--Growth of loblolly, shortleaf, and Virginia pines in the Tennessee Copper Basin (Study 6) on plots amended with sewage sludge or fertilizer after 10 years?

\begin{tabular}{|c|c|c|c|}
\hline Ireatment & Height & Diameter & $\mathrm{O}^{2} \mathrm{H}$ \\
\hline & $\mathrm{Cm}$ & $\underline{m m}$ & $\begin{array}{c}\mathrm{cm}^{3} \\
\times \quad 10,000) \\
\end{array}$ \\
\hline & \multicolumn{2}{|c|}{ LOBLOLLY } & \\
\hline \multirow[t]{2}{*}{$\begin{array}{l}\text { Sludye }{ }^{2} \\
\text { Fertilizer }\end{array}$} & $\begin{array}{l}702 a \\
450 b\end{array}$ & $\begin{array}{r}134 a \\
84 b\end{array}$ & $\begin{array}{r}135 a \\
40 b\end{array}$ \\
\hline & \multicolumn{2}{|c|}{ SHORTLEAF } & \\
\hline \multirow[t]{2}{*}{$\begin{array}{l}\text { Sludye } 2 \\
\text { Fertilizer }\end{array}$} & $\begin{array}{l}475 a \\
325 b\end{array}$ & $\begin{array}{l}77 a \\
54 b\end{array}$ & $\begin{array}{l}37 a \\
14 b\end{array}$ \\
\hline & \multicolumn{2}{|c|}{ VIRGINIA } & \\
\hline $\begin{array}{l}\text { Sludge } 2 \\
\text { Fertilizer }\end{array}$ & $\begin{array}{l}608 a \\
363 b\end{array}$ & $\begin{array}{r}124 a \\
72 b\end{array}$ & $\begin{array}{r}103 a \\
26 b\end{array}$ \\
\hline \multicolumn{4}{|c|}{$\begin{array}{l}\text { 'Within columns and species, means followed by the same letter do } \\
\text { not differ significantly at } \underline{p}=0.05 \text {. }\end{array}$} \\
\hline
\end{tabular}

Table 16.--Soil chemical properties of a good forest site planted with sweetgum with Orangeburg soil (Study 7) on the Savannah River Forest Station 1

\begin{tabular}{|c|c|c|c|c|c|c|c|c|}
\hline Treatment & $N$ & $P$ & $\underline{K}$ & $\mathrm{Ca}$ & $\mathrm{Mg}$ & O.M. & $\mathrm{pH}$ & CEC \\
\hline & - & $-\cdot$ & $-p / m$ & -- & - & $\underline{\underline{ }}$ & & $\mathrm{meq} / 100 \mathrm{~g}$ \\
\hline Sludge 2 & $605 a$ & $106 a$ & $57 a$ & $168 a$ & $18 a$ & $2.2 \mathrm{a}$ & $4.79 a$ & $2.2 a$ \\
\hline Fertilizer ${ }^{3}$ & $248 b$ & $36 b$ & $42 c$ & $94 b$ & $15 a$ & $1.6 \mathrm{~b}$ & $4.79 a$ & $1.3 b$ \\
\hline Control & $238 \mathrm{~b}$ & $31 b$ & $47 b$ & $111 \mathrm{~b}$ & $17 a$ & 1.60 & $4.96 \mathrm{a}$ & $1.4 \mathrm{~b}$ \\
\hline
\end{tabular}

'Within columns, means followed by the same letter do not differ significantly at $\underline{P}=0.05$.

$234 \mathrm{Mg} / \mathrm{ha}$.

${ }^{3} 280 \mathrm{~kg} / \mathrm{ha}$ of diammonium phosphate. 
Table 17.--Growth of sweetgum on a good forest site with Orangeburg soil (Study 7) after 2 years ${ }^{1}$

\begin{tabular}{|c|c|c|c|c|}
\hline Treatment & Survival & Height & Diameter & $\mathrm{D}^{2} \mathrm{H}$ \\
\hline & $\underline{q}$ & $\underline{\mathrm{cm}}$ & $\underline{\mathrm{mm}}$ & $\mathrm{cm}^{3}$ \\
\hline \multicolumn{5}{|c|}{ MINOR PLOTS } \\
\hline Sludge 2 & $88 a$ & $155 a$ & $37 a$ & $2417 a$ \\
\hline Fertilizer 3 & $83 a$ & $144 a$ & $36 a$ & $2] 48 a$ \\
\hline Control & $85 a$ & $123 b$ & $28 b$ & $1111 \mathrm{~b}$ \\
\hline \multicolumn{5}{|c|}{ MAJOR PLOTS } \\
\hline Subsoiled & $88 a$ & $147 a$ & $36 a$ & $2252 a$ \\
\hline Not subsoiled & $83 a$ & $134 b$ & $31 b$ & $1532 b$ \\
\hline \multicolumn{5}{|c|}{$\begin{array}{l}\text { 'Within columns for a particular series of plots, means followed by the same } \\
\text { letter do not differ significantly at } \underline{p}=0.05 \text {. }\end{array}$} \\
\hline
\end{tabular}

Table 18.--Soil chemical properties of a good forest site with Dothan and Norfolk soils (Study 8) planted with sweetgum on the Savannah River Forest Station!

\begin{tabular}{|c|c|c|c|c|c|c|c|c|}
\hline Treatment & $\mathbf{N}$ & $P$ & K & $\mathrm{Ca}$ & $\mathrm{Mg}$ & $0 . M$. & $\mathrm{pH}$ & CEC \\
\hline & - & - & $-p / \pi$ & - & -- & $\%$ & & $\mathrm{meq} / 100 \mathrm{~g}$ \\
\hline Sludge 2 & $725 a$ & $69 a$ & $47 a$ & $164 a$ & $30 a$ & $3.0 a$ & $4.83 b$ & $2.2 \mathrm{a}$ \\
\hline Fertilizer 3 & $492 b$ & $63 b$ & $51 \mathrm{a}$ & $143 a$ & $36 a$ & $2.6 a b$ & $4.88 a$ & $2.1 \mathrm{a}$ \\
\hline Control & $397 b$ & $8 b$ & $51 a$ & $144 a$ & $35 a$ & $2.2 \mathrm{~b}$ & $4.97 a$ & $2.0 \mathrm{a}$ \\
\hline
\end{tabular}

'Within columns, means followed by the same letter do not differ significantly at $\underline{P}=0.05$.

$234 \mathrm{Mg} / \mathrm{ha}$.

${ }^{3} 1480 \mathrm{~kg} / \mathrm{ha}$ diammonium phosphate, and $1100 \mathrm{~kg} / \mathrm{ha}$ of ammonium nitrate. 
Table 19.--Growth of sweetgum on Dothan and Norfolk soils (Study 8) at the Savannah River Forest Station, amended with sewage sludge or fertilizer after 7 years 1

\begin{tabular}{|c|c|c|c|c|}
\hline Treatment & Survival & Height & Diameter & $D^{2} H$ \\
\hline & $\underline{q}$ & $\underline{m}$ & $\mathrm{~cm}$ & $\begin{array}{c}\mathrm{cm}^{3} \\
\times \quad 10,000) \\
\end{array}$ \\
\hline Sludge 2 & $78 a$ & $5.29 a$ & $10.9 a$ & $7.1 \mathrm{a}$ \\
\hline Fertilizer 3 & $62 a$ & $4.25 b$ & $8.6 b$ & $3.6 \mathrm{~b}$ \\
\hline Control & $72 a$ & $4.31 b$ & $8.6 b$ & $3.6 \mathrm{~b}$ \\
\hline
\end{tabular}

'Within columns, means followed by the same letter do not differ significantly at $\underline{P}=0.05$.

$234 \mathrm{Mg} / \mathrm{ha}$.

${ }^{3} 1480 \mathrm{~kg} / \mathrm{ha}$ diammonium phosphate and $1100 \mathrm{~kg} / \mathrm{ha}$ ammonium nitrate.

Table 20.--Growth of loblolly and shortleaf pines on eroded forest land (Madison soil series) amended with sewage sludge after 5 years 1

\begin{tabular}{|c|c|c|c|c|c|}
\hline $\begin{array}{l}\text { Sludge } \\
\text { treatment } \\
\text { (Mg/ha) }\end{array}$ & Survival & Height & Diameter & $D^{2} H$ & $\begin{array}{c}\text { 1st-year } \\
\text { weed biomass }\end{array}$ \\
\hline & $\underline{\%}$ & $\underline{\mathrm{cm}}$ & $\mathrm{cm}$ & $\begin{array}{c}\mathrm{cm}^{3} \\
\times \quad 10,000) \\
\end{array}$ & $y / m^{2}$ \\
\hline \multicolumn{6}{|c|}{ LOBLOLLY PINE } \\
\hline $\begin{array}{r}0 \\
17 \\
34 \\
69\end{array}$ & $\begin{array}{l}96 a \\
86 a \\
67 a \\
67 a\end{array}$ & $\begin{array}{l}341 a \\
369 a \\
404 a \\
359 a\end{array}$ & $\begin{array}{r}8.3 a \\
9.0 a \\
9.9 a \\
10.4 a\end{array}$ & $\begin{array}{l}2.46 a \\
3.39 a \\
4.13 a \\
4.13 a\end{array}$ & $\begin{array}{l}121 c \\
341 b \\
321 b \\
475 a\end{array}$ \\
\hline \multicolumn{6}{|c|}{ SHORTLEAF PINE } \\
\hline $\begin{array}{r}0 \\
17 \\
34 \\
69\end{array}$ & $\begin{array}{l}68 a \\
77 a \\
42 b \\
--\end{array}$ & $\begin{array}{c}202 a \\
269 a \\
281 a \\
\ldots\end{array}$ & $\begin{array}{c}5.9 a \\
6.8 a \\
6.5 a \\
.-\end{array}$ & $\begin{array}{c}0.89 a \\
2.25 a \\
1.43 a \\
--\end{array}$ & $\begin{array}{r}91 d \\
228 c \\
370 b \\
563 a\end{array}$ \\
\hline
\end{tabular}

'Within columns and species, means followed by the same letter do not differ significantly at $\underline{P}=0.05$.

Source: Berry 1977. 
Table 21.--Chemical analysis of foliage of loblolly pine after yrowing 10 years on a borrow pit (Study 1 ) amended with sewage sludge or fertilizer'

\begin{tabular}{|c|c|c|c|c|c|c|c|c|c|c|c|c|c|}
\hline Treatment & $\mathrm{N}$ & $P$ & $K$ & $\mathrm{Ca}$ & $\mathrm{Mg}$ & $\mathrm{Mn}$ & $\mathrm{Fe}$ & Al & $B$ & $\mathrm{Cu}$ & $\mathrm{Zn}$ & $S r$ & $\mathrm{Ba}$ \\
\hline Fertilizer 3 & $0.84 a$ & $0.11 \mathrm{a}$ & $0.45 a$ & $0.20 \mathrm{~b}$ & $0.16 \mathrm{a}$ & $214 b$ & $24 \mathrm{~b}$ & $571 a$ & $12 b$ & $1.8 \mathrm{a}$ & $33 b$ & $4 a$ & $3 b$ \\
\hline Control & $0.73 b$ & $0.10 \mathrm{a}$ & $0.45 a$ & $0.18 b$ & $0.12 \mathrm{~b}$ & $342 a$ & $24 b$ & $559 a$ & $12 b$ & $1.8 \mathrm{a}$ & $33 b$ & $5 a$ & $7 b$ \\
\hline
\end{tabular}

'Within columns, means followed by the same letter do not differ significantly at $\underline{p}=0.05$.

${ }^{2} 34 \mathrm{Mg} / \mathrm{ha}$.

${ }^{3} 560 \mathrm{~kg} / \mathrm{ha}$ of $10-10-10$ fertilizer plus $2240 \mathrm{~kg} / \mathrm{ha}$ of dolomitic lime.

Table 22.--Chemical analysis of foliage of sweetgum after growing 10 years on a borrow pit (Study 2) amended with sewage sludge'

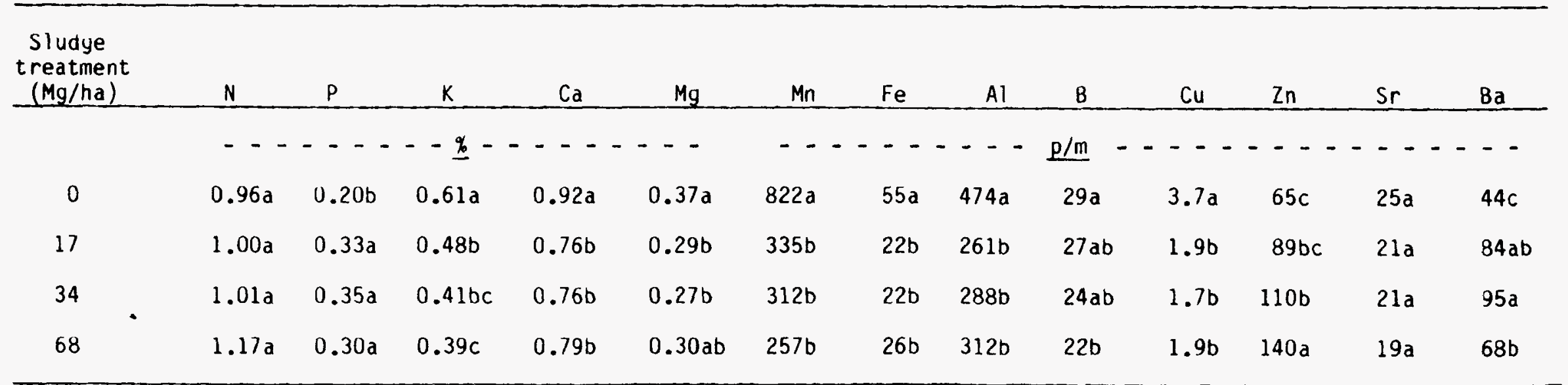

\footnotetext{
'Within columns, means followed by the same letter do not differ significantly at $\underline{P}=0.05$.
} 
Table 23.--Chemical analysis of foliage of loblolly pine after growing 7 years on a borrow pit (Study 3 ) amended with sewage sludge or fertilizer'

\begin{tabular}{|c|c|c|c|c|c|c|c|c|c|c|c|c|c|}
\hline Treatment & $\mathrm{N}$ & $p$ & $K$ & $\mathrm{Ca}$ & $\mathrm{Mg}$ & Mn & $\mathrm{Fe}$ & Al & $\mathrm{B}$ & $\mathrm{Cu}$ & $2 n$ & $S r$ & $\mathrm{Ba}$ \\
\hline & - & --- & $--\underline{x}-$ & $--\cdot$ & -- & -- & -- & -- & $\mathrm{p} / \mathrm{m}$ & $--\cdot$ & - & -- & -- \\
\hline Sludge 2 & $0.94 \mathrm{a}$ & $0.18 \mathrm{a}$ & $0.28 b$ & $0.30 \mathrm{a}$ & $0.15 b$ & $336 a$ & $30 a$ & $749 a$ & $12 \mathrm{a}$ & $2.1 \mathrm{a}$ & $58 a$ & $5 a$ & $8 a$ \\
\hline Fertilizer 3 & $0.73 b$ & $0.12 b$ & $0.59 a$ & $0.23 b$ & $0.18 \mathrm{a}$ & $120 \mathrm{~b}$ & $29 a$ & $712 a$ & $10 \mathrm{~b}$ & $1.2 b$ & $28 b$ & $4 b$ & $1 b$ \\
\hline
\end{tabular}

'Within columns, means followed by the same letter do not differ significantly at $\underline{p}=0.05$.

$217 \mathrm{Mg} / \mathrm{ha}$.

${ }^{3} 1120 \mathrm{~kg} / \mathrm{ha}$ of $10-10-10$ fertilizer plus $2240 \mathrm{~kg} / \mathrm{ha}$ of dolomitic lime. 
Table 24.--Chemical analysis of foliage of six forest tree species after growing 4 years on a borrow pit (Study 4) amended with sewage sludge or fertilizer'

\begin{tabular}{|c|c|c|c|c|c|c|c|c|c|c|c|c|c|}
\hline Treatment & $N$ & $P$ & $\underline{K}$ & $\mathrm{Ca}$ & $\mathrm{Mg}$ & Mn & $\mathrm{Fe}$ & Al & B & $\mathrm{Cu}$ & $2 n$ & $\mathrm{Sr}$ & $\mathrm{Ba}$ \\
\hline $\begin{array}{l}\text { Sludge } 2 \\
\text { Fertilizer } 3 \\
\text { Control }\end{array}$ & $\begin{array}{l}1.83 a \\
1.39 b \\
1.41 b\end{array}$ & $\begin{array}{l}0.27 \mathrm{a} \\
0.12 \mathrm{~b} \\
0.12 \mathrm{~b}\end{array}$ & $\begin{array}{l}0.47 \mathrm{~b} \\
0.71 \mathrm{a} \\
0.61 \mathrm{ab}\end{array}$ & $\begin{array}{l}0.72 a \\
0.56 a \\
0.55 a\end{array}$ & $\begin{array}{l}0.26 a \\
0.22 a \\
0.26 a\end{array}$ & $\begin{array}{l}37 a \\
22 a \\
35 a\end{array}$ & $\begin{array}{l}60 a \\
47 a \\
66 a\end{array}$ & $\begin{array}{r}46 a \\
56 a \\
140 a\end{array}$ & $\begin{array}{l}19 b \\
25 b \\
33 a\end{array}$ & $\begin{array}{l}27.4 a \\
16.4 a \\
30.6 a\end{array}$ & $\begin{array}{l}36 a \\
17 b \\
16 b\end{array}$ & $\begin{array}{l}17 a b \\
9 b \\
21 a\end{array}$ & $\begin{array}{r}21 a \\
9 b \\
12 b\end{array}$ \\
\hline $\begin{array}{l}\text { Sludye } 2 \\
\text { Fertilizer } \\
\text { Control }\end{array}$ & $\begin{array}{l}1.79 a \\
1.06 b \\
1.00 b\end{array}$ & $\begin{array}{l}0.24 a \\
0.09 b \\
0.11 b\end{array}$ & $\begin{array}{l}0.37 b \\
0.48 a \\
0.39 b\end{array}$ & $\begin{array}{l}0.72 b \\
0.93 a b \\
0.97 a\end{array}$ & $\begin{array}{l}0.34 b \\
0.47 a \\
0.43 a\end{array}$ & $\begin{array}{l}703 a . \\
356 b \\
659 a\end{array}$ & $\begin{array}{l}47 a \\
36 a \\
64 a\end{array}$ & $\begin{array}{l}353 b \\
402 b \\
568 a\end{array}$ & $\begin{array}{l}27 a \\
29 a \\
28 a\end{array}$ & $\begin{array}{l}7.8 a \\
4.4 b \\
4.5 b\end{array}$ & $\begin{array}{r}129 a \\
26 b \\
35 b\end{array}$ & $\begin{array}{l}13 b \\
13 b \\
40 a\end{array}$ & $\begin{array}{l}23 a \\
11 a \\
22 a\end{array}$ \\
\hline \multicolumn{14}{|c|}{ LOBLOLLY PINE } \\
\hline $\begin{array}{l}\text { Sludge } 2 \\
\text { Fertilizer }{ }^{3} \\
\text { Control }\end{array}$ & $\begin{array}{l}1.51 \mathrm{a} \\
1.09 \mathrm{~b} \\
1.08 \mathrm{~b}\end{array}$ & $\begin{array}{l}0.17 a \\
0.12 b \\
0.13 b\end{array}$ & $\begin{array}{l}0.33 a \\
0.41 a \\
0.33 a\end{array}$ & $\begin{array}{l}0.22 a \\
0.18 a \\
0.17 a\end{array}$ & $\begin{array}{l}0.10 b \\
0.13 a \\
0.14 a\end{array}$ & $\begin{array}{l}368 a \\
125 b \\
196 a b\end{array}$ & $\begin{array}{l}34 a \\
24 b \\
23 b\end{array}$ & $\begin{array}{l}557 b \\
601 a b \\
686 a\end{array}$ & $\begin{array}{c}12 a \\
9 b \\
11 a b\end{array}$ & $\begin{array}{l}3.6 \mathrm{a} \\
1.9 \mathrm{~b} \\
1.8 \mathrm{~b}\end{array}$ & $\begin{array}{l}69 a \\
21 b \\
23 b\end{array}$ & $\begin{array}{l}3 a \\
3 a \\
5 a\end{array}$ & $\begin{array}{l}1 \mathrm{a} \\
1 \mathrm{a} \\
2 \mathrm{a}\end{array}$ \\
\hline \multicolumn{14}{|c|}{ SAWTOOTH OAK } \\
\hline $\begin{array}{l}\text { Sludge } 2 \\
\text { Fertilizer }\end{array}$ & $\begin{array}{l}2.20 \mathrm{a} \\
1.70 \mathrm{a}\end{array}$ & $\begin{array}{l}0.20 a \\
0.11 b\end{array}$ & $\begin{array}{l}0.42 \mathrm{~b} \\
0.66 \mathrm{a}\end{array}$ & $\begin{array}{l}0.50 \mathrm{~b} \\
0.55 \mathrm{a}\end{array}$ & $\begin{array}{l}0.19 b \\
0.27 a\end{array}$ & $\begin{array}{l}363 a \\
182 b\end{array}$ & $\begin{array}{l}62 a \\
47 b\end{array}$ & $\begin{array}{l}51 a \\
69 a\end{array}$ & $\begin{array}{l}42 a \\
43 a\end{array}$ & $\begin{array}{l}7.8 a \\
5.3 b\end{array}$ & $\begin{array}{l}42 a \\
20 b\end{array}$ & $\begin{array}{r}21 a \\
7 a\end{array}$ & $\begin{array}{l}29 a \\
25 a\end{array}$ \\
\hline \multicolumn{14}{|c|}{ SYCAMORE } \\
\hline $\begin{array}{l}\text { Sludge } 2 \\
\text { Fertilizer }\end{array}$ & $\begin{array}{l}2.27 a \\
1.39 b\end{array}$ & $\begin{array}{l}0.21 \mathrm{a} \\
0.10 \mathrm{~b}\end{array}$ & $\begin{array}{l}0.44 a \\
0.49 a\end{array}$ & $\begin{array}{l}0.94 a \\
0.99 a\end{array}$ & $\begin{array}{l}0.34 a \\
0.43 a\end{array}$ & $\begin{array}{l}267 a \\
107 a\end{array}$ & $\begin{array}{l}48 a \\
39 a\end{array}$ & $\begin{array}{l}37 a \\
48 a\end{array}$ & $\begin{array}{l}35 a \\
29 a\end{array}$ & $\begin{array}{r}13.7 a \\
5.2 b\end{array}$ & $\begin{array}{l}52 a \\
14 b\end{array}$ & $\begin{array}{l}26 a \\
27 a\end{array}$ & $\begin{array}{l}28 a \\
14 a\end{array}$ \\
\hline \multicolumn{14}{|c|}{ YELLOW-POPLAR } \\
\hline $\begin{array}{l}\text { Sludge } 2 \\
\text { Fertilizer }\end{array}$ & $\begin{array}{l}2.05 a \\
1.22 b\end{array}$ & $\begin{array}{l}0.16 a \\
0.08 \mathrm{~b}\end{array}$ & $\begin{array}{l}0.31 \mathrm{~b} \\
0.55 \mathrm{a}\end{array}$ & $\begin{array}{l}1.25 a \\
1.41 a\end{array}$ & $\begin{array}{l}0.51 a \\
0.54 a\end{array}$ & $\begin{array}{l}514 a \\
207 b\end{array}$ & $\begin{array}{l}41 a \\
37 a\end{array}$ & $\begin{array}{l}286 a \\
447 a\end{array}$ & $\begin{array}{l}44 a \\
37 a\end{array}$ & $\begin{array}{l}6.8 a \\
3.5 b\end{array}$ & $\begin{array}{l}28 a \\
12 a\end{array}$ & $\begin{array}{l}41 a \\
42 a\end{array}$ & $\begin{array}{l}32 a \\
16 b\end{array}$ \\
\hline
\end{tabular}

${ }_{2}^{1} W i$ thin columns and species, means followed by the same letter do not differ significantly at $\underline{p}=0.05$. $268 \mathrm{Mg} / \mathrm{ha}$.

$31120 \mathrm{~kg} / \mathrm{ha}$ of $10-10-10$ fertilizer plus $2240 \mathrm{~kg} / \mathrm{ha}$ of dolomitic lime. 
Table 25.--Chemical analysis of foliage of sweetgum after growing 4 years on kaolin spoil (Study 5) amended with sewage sludge or fertilizer ${ }^{1}$

\begin{tabular}{|c|c|c|c|c|c|c|c|c|c|c|c|c|c|}
\hline & $-\cdots$ & -- & -- & -- & -- & -- & -- & -- & - & -- & -- & -- & -- \\
\hline Fertilizer 3 & $0.73 b$ & $0.25 b$ & $0.73 a$ & $0.89 a$ & $0.51 \mathrm{a}$ & $769 a$ & $72 a b$ & $508 a$ & $30 a$ & $2.7 b$ & $40 \mathrm{~b}$ & $6 a$ & $27 b$ \\
\hline Control 4 & $0.83 \mathrm{~b}$ & $0.10 c$ & $0.60 \mathrm{~b}$ & $0.82 a$ & $0.46 a$ & $6 b 4 b$ & $85 a$ & $521 a$ & $25 a b$ & $3.4 \mathrm{~b}$ & $38 \mathrm{~b}$ & $7 a$ & $25 b$ \\
\hline
\end{tabular}

'Within columns, means followed by the same letter do not differ significantly at $\underline{p}=0.05$.

$234 \mathrm{Mg} / \mathrm{ha}$.

${ }^{3} 1120 \mathrm{~kg} / \mathrm{ha}$ of $10-10-10$ fertilizer plus $2240 \mathrm{~kg} / \mathrm{ha}$ of dolomitic lime.

${ }^{4} 2240 \mathrm{~kg} / \mathrm{ha}$ of dolomitic lime. 
Table 26.--Chemical analysis of foliage of loblolly, shortleaf, and Virginia pines after growing 10 years in the Tennessee Copper Basin (Study 6) on plots amended with sewage sludge or fertilizer'

\begin{tabular}{|c|c|c|c|c|c|c|c|c|c|c|c|c|c|}
\hline Shortleaf & $1.06 a b$ & $0.26 \mathrm{~b}$ & $0.65 a$ & $0.28 \mathrm{c}$ & $0.09 a$ & $1415 b$ & $206 a$ & $856 a$ & $15 b$ & $9.4 a b$ & $5 b a$ & $5 b$ & $17 b$ \\
\hline Virginia & $1.11 \mathrm{a}$ & $0.30 \mathrm{a}$ & $0.44 b$ & $0.47 \mathrm{a}$ & $0.08 b$ & $2165 a$ & $206 a$ & $824 a$ & $28 a$ & $8.4 b$ & $43 b$ & $7 a$ & $44 a$ \\
\hline fertilizer 3 & 1.018 & $0.24 B$ & $0.54 \mathrm{~A}$ & $0.35 \mathrm{~A}$ & $0.08 \mathrm{~A}$ & $1483 A$ & $192 B$ & $717 \mathrm{~A}$ & $18 \mathrm{~A}$ & $8.6 \mathrm{~B}$ & $48 B$ & $5 A$ & $19 \mathrm{~A}$ \\
\hline
\end{tabular}

'For a particular species and nutrient, means followed by the same lowercase letter do not differ significantiy at $P=0.05$. For a particular nutrient, means followed by the same uppercase letter do not differ significantly at $\bar{P}=0.05$.

$234 \mathrm{Mg} / \mathrm{ha}$.

${ }^{3} 896 \mathrm{~kg} / \mathrm{ha}$ of $10-10-10$ fertilizer plus $1417 \mathrm{~kg} / \mathrm{ha}$ of $\mathrm{Ca} 0$. 
Table 27.--Chemical analysis of foliage of sweetgum after growing 2 years on a good forest site with Orangeburg soil (Study 7) amended with sludye or fertilizerl

\begin{tabular}{|c|c|c|c|c|c|c|c|c|c|c|c|c|c|}
\hline Treatment & $N$ & $P$ & $K$ & $\mathrm{Ca}$ & $\mathrm{Mg}$ & $M n$ & $\mathrm{Fe}$ & Al & $B$ & $\mathrm{Cu}$ & $2 n$ & $\mathrm{Sr}$ & $\mathrm{Ba}$ \\
\hline & -- & --- & -- & --- & -- & -- & - & -- & $/ m$ & -- & - & - & -- \\
\hline Sludge 2 & $2.33 a$ & $0.20 \mathrm{a}$ & $0.66 a$ & $0.57 \mathrm{~b}$ & $0.29 \mathrm{~b}$ & $598 a$ & $46 a$ & $326 a b$ & $16 b$ & $6.9 b$ & $26 c$ & $18 a$ & $107 b$ \\
\hline Fertilizer 3 & $2.15 b$ & $0.20 a$ & $0.56 \mathrm{~b}$ & $0.67 a$ & $0.27 b$ & $452 b$ & $39 b$ & $278 b$ & $23 a$ & 8.2 & $51 \mathrm{a}$ & $18 a$ & $77 b$ \\
\hline Control & $1.74 c$ & $0.19 a$ & $0.65 a$ & $0.66 a$ & $0.37 a$ & $493 b$ & $39 b$ & $386 a$ & $17 \mathrm{~b}$ & $9.9 a$ & $39 b$ & $21 a$ & $149 a$ \\
\hline
\end{tabular}

'Within columns, means followed by the same letter do not differ significantly at $\underline{P}=0.05$.

$234 \mathrm{Mg} / \mathrm{ha}$.

${ }^{3} 280 \mathrm{~kg} / \mathrm{ha}$ diammonium phosphate.

Table 28.--Chemical analysis of foliage of sweetgum after growing 7 years on a good forest site with Dothan and Norfolk soils (Study 8) amended with sludge or fertilizer'

\begin{tabular}{|c|c|c|c|c|c|c|c|c|c|c|c|c|c|}
\hline Treatment & $N$ & $P$ & $K$ & $\mathrm{Ca}$ & $\mathrm{Mg}$ & Mn & $\mathrm{Fe}$ & $\mathrm{Al}$ & B & $\mathrm{Cu}$ & $\mathrm{Zn}$ & $\mathrm{Sr}$ & $\mathrm{Ba}$ \\
\hline & -- & -- & -- & -- & - & -- & - & -- & $\mathrm{p} / \mathrm{m}$ & -- & & - & - \\
\hline Sludge 2 & $1.47 b$ & $0.23 a$ & $0.45 a$ & $0.73 a$ & $0.41 \mathrm{a}$ & $604 a$ & $34 a$ & $498 a$ & $30 a b$ & $5.5 b$ & $44 b$ & $16 a$ & $29 b$ \\
\hline Fertilizer 3 & $1.67 a$ & $0.26 \mathrm{a}$ & $0.48 \mathrm{a}$ & $0.73 \mathrm{a}$ & $0.39 a$ & $560 a$ & $33 a$ & $498 a$ & $27 b$ & $6.8 a$ & $92 a$ & $18 a$ & $72 a$ \\
\hline Control & $1.16 \mathrm{C}$ & $0.14 b$ & $0.43 a$ & $0.70 \mathrm{a}$ & $0.37 a$ & $552 a$ & $28 b$ & $473 a$ & $32 a$ & $4.0 c$ & $42 b$ & $16 a$ & $28 b$ \\
\hline
\end{tabular}

'Within columns, means followed by the same letter do not differ significantly at $\underline{P}=0.05$.

$234 \mathrm{Mg} / \mathrm{ha}$.

w $\quad{ }^{3} 1480 \mathrm{~kg} / \mathrm{ha}$ diammonium phosphate plus $1100 \mathrm{~kg} / \mathrm{ha}$ ammonium nitrate. 
Berry, Charles R.

Use of municipal sewage sludge for improvement of forest sites in the Southeast. Res. Pap. SE-266. Asheville, MC. U.S. Department of Agriculture, Forest Service, Southeastern Forest Experiment Station. 1987. $33 \mathrm{pp}$.

In eight field experiments dried municipal sewage sludge was applied to forest sites before planting of seedlings. In all cases, tree growth was faster on sludge-amended plots than on plots that received fertilizer and lime or no amendment. Deep subsoiling was beneficial regardless of soil amendment. there weeds were plentiful at the outset, they became serious competitors on plots receiving sludge.

KEYWORDS: Reclamation, borrow pit, tree growth, Pinus taeda,

Liquidambar styraciflua, soil nutrients, subsoiling.
Berry, Charles R.

Use of municipal sewage sludge for improvement of forest sites in the Southeast. Res. Pap. SE-266. Asheville, NC: U.S. Department of Agriculture, Forest Service, Southeastern forest Experiment Station. 1987. $33 \mathrm{pp}$.

In eight field experiments dried municipal sewage sludge was applied to forest sites before planting of seedlings. In all cases, tree growth was faster on sludge-amended plots than on plots that received fertilizer and lime or no amendment. Deep subsoiling was beneficial regardless of soil amendment. Where weeds were plentiful at the out set, they became serious competitors on plots receiving sludge.

KEYWORDS: Reclamation, Dorrow pit, tree growth, Pinus taeda, Liquidambar styraciflua, soil nutrients, subsoiling. 
The Forest Service, U.S. Department of Agriculture, is dedicated to the principle of multiple use management of the Nation's forest resources for sustained yields of wood, water, forage, wildlife, and recreation. Through forestry research, cooperation with the States and private forest owners, and management of the National Forests and National Grasslands, it strives-as directed by Congress - to provide increasingly greater service to a growing Nation.

USDA policy prohibits discrimination because of race, color, national origin, sex, age, religion, or handicapping condition. Any person who believes he or she has been discriminated against in any USDA-related activity should immediately contact the Secretary of Agriculture, Washington, DC 20250. 